\title{
The Mental Hospitalization of Children and the Limits of Parental Authority
}

In many states the law permits parents to admit their children to mental hospitals with no more formality than the approval of hospital officials. ${ }^{1}$ In practice, such laws have allowed children to be confined to mental hospitals for reasons unrelated to their own mental health, 2 even if the children themselves object. But since psychiatric hospitalization $^{3}$ to which the individual himself does not consent is a "massive

1. See, e.g., ARk. Stat. ANN. \$ 59-405 (1971); Colo. Rev. Stat. § 27-10-103(3) (1973); Del. Code ANN. tit. $16 \$ 5123$ (1974); INd. Code ANN. \$ 16-14-9.1-2 (Burns Supp. 1977); KY. Rev. Stat. \$ 202A.020 (1977); ORE. Rev. STAT. $\$ 426.220$ (1977). In some states the statutes clearly allow parents to admit their children to mental hospitals but are ambiguous about whether the child's request for release will be given legal effect. See, e.g., Haw. REv. Srat. $\$ 334-60$ (1976); Ill. ANN. STAT. ch. 911/2, $\$ 5-2$ to -3 (Smith-Hurd Supp. 1978); Miss. Code AnN. \$ 41-21-103 (Supp. 1977); Nev. Rev. Stat. \$ 433A.140 (1976); Tex. Rev. Civ. Stat. ANN. art. 5547-23 to .24 (Vernon 1958). In some other states parental admission is allowed, but the child's request for release is expressly given legal effect. See In re Williams, 140 N.J. Super. 495, 498-99, 356 A.2d 468, 470-71 (Juv. \& Dom. Rel. Ct. 1976) (interpreting N.J. Rev. Stat. ANN. \$ 30:4-48 (West Supp. 1977)); Mont. Rev. Codes ANN. $\$ 38-1303$ (Supp. 1977); N.Y. Mental Hyg. Law $\$ 9.13$ (McKinney Supp. 1977); cf. S.C. Code $\$ 44-17-310$ (Supp. 1977) (minor's request subject to 14-day notice to parents). A few states provide mechanisms for judicial review of parental admissions. See Mich. CoMp. Laws ANn. $\$ 330.1415-.1418$ (1971) (minor at least 13 years old or other suitable person may initiate proceedings); Ohio Rev. Code ANN. \$ 5122.02 (Page Supp. 1978) (review automatic); PA. STAT. ANN. tit. 50, $\$ 7206$ (Purdon Supp. 1978) (any responsible party may initiate proceedings); S.D. Cod. LAws $\$ 27$ A-8-4 to -6 (Supp. 1977) (minor may initiate proceedings); Wis. STAT. ANN. \$ 51.10 (West Supp. 1977) (review automatic). Some states provide that once a child attains a certain age, his own consent (sometimes in conjunction with his parents') is required for admission. See HAw. REv. STAT. $\$ 334-60$ (1976) (15 years old; joint consent); N.M. STAT. ANN. \$ 34-2-2, -4 (1953) (16 years old); OKLA. STAT. ANN. tit. 43A, $\$ 53$ (West Supp. 1977) (16 years old; joint consent); PA. STAT. ANN. tit. 50, $\$ 7201$ (Purdon Supp. 1977) (14 years old); TENN. CodE ANN. \$ 33-601 (1977) (16 years old); S.C. Code $\$ 44-17-310$ (Supp. 1977) (16 years old); Utak Code ANN. $\$ 64-7-29$ (1977) (16 years old); WASH. REv. CODE ANN $\$ 72.23 .070$ (1977) (13 years old); Wis. Stat. ANN. $\$ 51.10$ (West Supp. 1977) (14 years old). Montana is unique in providing that parental admission automatically terminates after one year unless continuation is consented to by the minor and his counsel. See Mont. Rev. Codes ANN. \$ 38-1303(8) (Supp. 1977).

2. Truancy, promiscuity, theft, ungovernability, and the convenience of other family members are among the underlying reasons for the psychiatric hospitalization of some children. See note 46 infra; J.L. v. Parham, 412 F. Supp. 112, 138 (M.D. Ga. 1976), prob. juris. noted, 431 U.S. 936 (1977), set for reargument, 98 S. Ct. 761 (1978) (No. 75-1690) (some parents "abandon their child to the state"); Bartley v. Kremens, 402 F. Supp. 1039. 1044 (E.D. Pa. 1975), vacated and remanded as moot, 431 U.S. 119 (1977) (giving examples of hospitalization for family convenience); In re Aslanian, 318 Mich. 55, 59, 27 N.W.2d 343, 344 (1947) (girl committed to mental hospital by father in part because she was a "sex delinquent").

3. In this Note, "psychiatric hospitalization" refers to the placement of an individual in a mental hospital, i.e., a residential facility for the care and treatment of the mentally ill, see Jolvt Comissios on Acckeditation of Hospitals, Accreditation Mindal for 
curtailment of liberty," 4 statutes authorizing parents to admit their children to mental hospitals may be challenged as depriving children of liberty without due process of law. Bartley $v$. Kremens ${ }^{5}$ and other recent cases ${ }^{6}$ have invalidated such statutes on that ground.

Although these cases, among others, ${ }^{\bar{\top}}$ imply that there are constitutional limits on the power of parents to make choices for their children, there has not yet been a satisfactory account of what those limits are. Consequently, courts and legislatures have been left without guidance concerning the constitutionally acceptable alternatives to unfettered parental discretion. ${ }^{8}$ This Note will make a constitutional argument for limiting parental authority with respect to the psychiatric hospital-

Psychiatric Facilities Serving Children ANd Adolescents 124-25 (1974) (defining types of treatment facilities). Experts in the field also distinguish between two kinds of residential facility: residential treatment centers (RTCs) and psychiatric hospitals. See National. INstitute of Mental Health, Residential Psychiatric Facilities for Children and AdoLesCents: United States, 1971-72, at 3 (Mental Health Facility Res. Ser. A, No. 14, 1974) [hereinafter cited as NIMH]. Although usage varies somewhat, it seems that as compared to psychiatric hospitals, RTCs treat slightly less disturbed children, focus more on education and adjustment to social life than on psychiatric treatment per se, and are more open to the community. See Joint Commission on Mental Health of Children, Mental Health: From INfancy Through Adolescence 305.06 (1973) [hereinafter cited as Joint Commission]; Day, Treatment Models for Adolescents: Residential Treatment Center vs. Hospital, J. Nat'l A. Private Psych. Hospitals, Winter 1972-73, at 25, 27. RTCs account for about one-fifth of the residential treatment of children and adolescents, see NIMH, supra, at 2 (Table A), and are generally privately owned, see id. at 5 (Table B). This Note discusses only psychiatric hospitals, but the argument applies to RTCs to the extent that they pose an equal threat to the child's liberty.

4. Humphrey v: Cady, 405 U.S. 504, 509 (1972); see pp. 188-89 \& note 14 infra (liberty interests affected by psychiatric hospitalization are constitutionally protected).

5. 402 F. Supp. 1039 (E.D. Pa. 1975), vacated and remanded as moot, 431 U.S. 119 (1977), on remand sub nom. Secretary of Pub. Welfare $v$. Institutionalized Juveniles (E.D. Pa. May 25, 1978), prob. juris. noted, 98 S. Ct. 3087 (1978) (No. 77-1715) (invalidating parental admission under PA. STat. ANx. tit. 50, $\$ \$ 4402,4403$ (Purdon 1969) (statute repealed except as applied to mental retardation in 1976).

6. J.L. v. Parham, 412 F. Supp. 112 (M.D. Ga. 1976), prob. juris. noted, 431 U.S. 936 (1977), set for reargument, 98 S. Ct. 761 (1978) (No. 75-1690) (invalidating parental admission under GA. CodE ANN. \$ 88-503.1 (1971)); In re Roger S., 19 Cal. 3d 921, 569 P.2d 1286, 141 Cal. Rptr. 298 (1977) (invalidating parental admission under CAL. WELF. \& INST. CODE $\$ 6000$ (b) (West 1972) (amended 1978)); cf. Saville v. Treadway, 404 F. Supp. 430 (M.D. Tenn. 1974) (parental admission to institution for mental retardation). But see In re Long, 25 N.C. App. 702, 214 S.E.2d 626 (1975), cert. denied, 288 N.C. 241, 217 S.E.2d 665 (1975) (parental admission constitutionally permissible provided minor has adequate opportunity to challenge continued confinement).

7. See Planned Parenthood v. Danforth, 428 U.S. 52, $72-75$ (1977) (invalidating require. ment of parental consent for abortion); $T_{-} H_{-}$v. Jones, $425 \mathrm{~F}$. Supp. 873, 880.82 (D. Utah 1977) (invalidating requirement of parental consent for access to contraceptives) (alternative holding). But see Doc v. Irwin, 441 F. Supp. 1247 (W.D. Mich. 1977) (enjoining family planning center from distributing contraceptives to minors without notice to parents).

8. For example, compare Bartley, 402 F. Supp. at 1041-45, 1053-54 (requiring hearing for all children placed in public or private hospitals), with In re Roger S., 19 Cal. 3d 921, 927 n.3, 931, 569 P.2d 1286, 1289 n.3, 1292, 141 Cal. Rptr. 298, 301 n.3, 304 (1977) (requiring licaring only for children 14 ycars old and orer placed in public mental hospitals). 
ization of children. In addition, the method used applies to other contexts in which the authority of parents and the rights of children collide.

Part I of the Note argues that the resolution of the children's rights issue raised in cases like Bartley hinges on an analysis of the constitutionally legitimate scope of parental authority. Part II undertakes such an analysis and establishes the substantive limits on a parent's power to place his child in a mental hospital. Aided by this discussion, Part III considers what procedures for the psychiatric hospitalization of children would be constitutionally adequate and concludes that this depends on the age of the child. According to this analysis, pre-adolescent children may be admitted to mental hospitals by their parents; a hearing is not necessary provided there are other procedures adequate to protect them against abuses of parental discretion. Parental control over the psychiatric hospitalization of an adolescent must, however, be more limited; before an adolescent may be confined to a mental hospital against his will, he has a constitutional right to be heard.

\section{Children's Liberty and Parental Authority}

Any person admitted to a mental hospital is subject to restriction on his movements and associations, ${ }^{9}$ which may include an institutional regimentation encompassing virtually every facet of his life. ${ }^{10}$ After

9. Mental health statutes do not reveal any significant difference between the rights of voluntary and involuntary patients with respect to correspondence, visitation, mechanical restraints, and the exercise of civil rights. American Bar Foundation, The Mentally Disabled and the Law 20-21 (rev. ed. S. Brakel \& R. Rock 1971). A voluntary patient, like an involuntary one, may be limited in his communications and access to visitors, see, e.g., GA. Code ANN. $\$ 88-502.5$ (1971); Mich. Comp. Laws ANN. $\$ 330.1726(4)$, (6) (1975), and may be controlled with mechanical restraints or forced seclusion, see, e.g., Ga. Code ANN. \$ 88-502.4 (1971) (mechanical restraints); Mich. Comp. Laws ANN. $\$ \S 330.1740$, .1742 (1975) (mechanical restraints, seclusion); Goldsmith, Residential Treatment Today: The Paradox of New Premises, 46 AM. J. ORTHOPsYch. 425, 433 (1976) (increasing use of physical restraints and isolation for children and adolescents). Not infrequently such restrictions are used punitively to preserve institutional order. Sec Developments in the Law-Civil Commitment of the Menlally Ill, 87 Harv. L. REv. 1190, 1358-61 (1974) [hereinafter cited as Developments]. In many states, a paticnt who leaves hospital grounds without proper authority is subject to arrest. See, e.g., Ill. ANN. Stat.

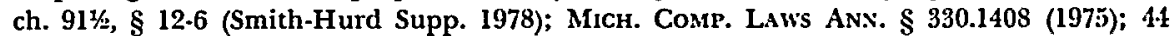
N.C. ATr'Y GEN. 52 (1974) (statutory provision unnecessary). In addition, in many jurisdictions, a voluntary patient may be detained temporarily if he requests to leave. See, e.g., Conn. Gen. Stat. \$ 17-187 (1977); GA. Code AnN. \$ 88-503.1 (1971); Mich. Comp. Luws ANN. \$ 330.1419 (1975).

10. See J.L. v. Parham, 412 F. Supp. 112, 137 (M.D. Ga. 1976), prob. juris. noted, 431 U.S. 936 (1977), set for reargument, 98 S. Ct. 761 (1978) (No. 75-1690); Rinsley, Theory and Practice of Intensive Residential Treatment of Adolescence, in 1 Adolescent PsychiATRY 419, 486, 488, 503 (S. Feinstein, P. Giovacchini \& A. Miller eds. 1971) ("scverely ill" adolescents require carefully "titrated" behavioral restrictions that include isolation from 
his release a mental patient may, because of his former status, confront social opprobrium ${ }^{11}$ and legal disabilities. ${ }^{12}$ The very fact that one has been hospitalized may cause a loss of self-esteem. ${ }^{13}$ Thus, psychiatric hospitalization, even when voluntary, impinges on individual liberty interests that are generally accorded constitutional protection. ${ }^{14}$ The curtailment of liberty is severe for a child who is confined to a mental hospital by his parents' consent but against his will. To the extent the state itself is involved in such hospitalizations, ${ }^{15}$

family, community, and sometimes fellow patients); Wing, Institutionalism in Mental Hospitals, in Mental Illiness and Social Processes 220-21 (T. Scheff ed. 1967) ("The inmates sleep, play and work in one place, and an overall rational plan guides all behaviour.")

A tendency toward regimentation and intrusion on privacy in a mental hospital is simply a consequence of its organizational structure. N. HOBBS, THE FUTURES of CHILDREN 126 (1975) (citing two studies contrasting hospitals to group homes and hostels); see Brief for Appellees at 26, Parham v. J.L., 431 U.S. 936 (1977), set for reargument, 98 S. Ct. 761 (1978) (noting probable jurisdiction from 412 F. Supp. 112, 138 (M.D. Ga. 1976)) (No. 75-1690) (testimony of Dr. Eli Charles Messinger) ("[N]o matter how forward looking and progressive the institution, there is inevitably some tendency to sacrifice the needs of the individual patient for the needs of institutional efficiency"); N. HOBBs, supra, at 130-34 (regimentation results from overcrowding and poor staff training characteristic of public psychiatric hospitals for children). See generally E. Goffman, On the Characteristics of Total Institutions, in Asycums (1961) (general theory of "total institutions").

11. The social stigma of mental illness seems to attach to voluntary mental patients as well as involuntary ones, see $\mathrm{H}$. KAPLAN, THE Sociology of MENTAL. Illness 130.36 (1972) (citing studies); Developments, sutpra note 9, at 1200, and to children as well as adults, see M. Grob \& J. Singer, Adolescent Patients in Transition 117 (1974); Weiss \& Pizer, Hospitalizing the Young: Is It For Their Own Good? 54 Mental Hygrene 498, 50001 (1970). But see Schwartz, Myers \& Astrachan, Psychiatric Labeling and the Rehabilitation of the Mental Patient, 31 Archives General Psych. 329, 333 (1974) ("[T] he stigma of mental hospitalization is not a major problem for the ex-patient.")

12. See American B.ar Found.ation, supra note 9, at 307-08; Ennis, Legal Rights of the Voluntary Palient, J. Nit'L A. Private Psych. Hospitals, Summer 1976, at 4; Weiss \& Pizer, supra note 11 , at 501 .

13. See Anthony, The Reaclion of Adults to Adolescents and Their Behavior, in Adolescence: Psychosocial. Persiectives 65 (G. Caplan \& S. Lebovici eds. 1969) (referral of adolescent to psychiatrist may confirm inner apprehension of incipient insanity); Weiss \&. Pizer, supra note 11, at 501; Developments, supra note 9, at 1200.

14. See Ingraham v. Wright, 431 U.S. 651, 673-74 (1977) (constitutionally protected liberty includes freedom from bodily restraint and punishment); Paul v. Davis, 424 U.S. $645,708.09$ (1976) (social stigma plus altered legal status constitute deprivation of liberty within meaning of 14th Amendment); O'Connor v. Donaldson, 422 U.S. 563, 576 (1975) (confinement in mental hospital of adult capable of living outside safely, by himself or with lielp of others, is deprivation of constitutionally protected liberty); In re Gault, 387 U.S. 1, 27-31 (1967) (threat of juvenile's incarceration in delinquency institution implicates due process clause).

15. The threshold requirement of "state action" clearly is satisfied when the child is admitted to a state-operated or state-controlled mental hospital, because state hospital not only approres the parents' request for hospitalization but also imposes the confinement itself. See In re Roger S., 19 Cal. 3d 921, 928, 569 P.2d 1286, 1290, 141 Cal. Rptr. 298, 302 (1977).

There may also be "state action" where the child is admitted to a hospital that is not under state control. Two theories would support this view. First, the private exercise of an "exclusively public function" is "state action." See Flagg Bros. v. Brooks, 98 S. Ct. 1729, 1734-37 (1978). To the extent that the decision to confine a child involuntarily to a mental 


\section{the Fourteenth Amendment's due process guarantees ${ }^{10}$ apply. ${ }^{17}$}

An adult's consent to his own hospitalization may by itself satisfy whatever due process guarantees apply, for this decision is within the scope of autonomy society grants to adults. ${ }^{18} \mathrm{~A}$ hearing concerning such a hospitalization would be singularly out of place, since the state (or the private entity acting under state auspices) is simply complying with the individual's request. Where one person is consenting to the psychiatric hospitalization of another, however, the situation is more complex.

The statutory provisions challenged in Bartley and the other cases in this area were elaborations of the state's general statutory procedure for voluntary admission to a mental hospital. By these statutes, which gave the parent's choice for his child the same legal effect as an adult's choice for himself, the state sanctioned parental authority-that is, the prerog-

hospital is traditionally a function of the government, the prerequisites for state action are met. Second, certain cases suggest the principle that there is state action whenever the state expressly authorizes a private individual to act in derogation of the constitutional rights of another. See Reitman v. Mulkcy, 387 L.S. 369, 375-76, 381 (1967); Burton v. W'ilmington Parking Authority, 365 U.S. 715, 726 (1961) (Stewart, J., concurring). But see Flagg Bros. v. Brooks, $98 \mathrm{~S}$. Ct. 1729, 1737 (1978) (state acquiescence in private conduct is not state action). See generally Burke \& Reber, State Action, Congressional Power and Creditors' Rights: An Essay on the Fourteenth Amendment (pt. 1), 46 S. CaL. L. Rev. 1003, 1096 1109 (1973). Where the stakes include competing interests in property, express authorization is not by itsclf a sufficient basis for state action. Flagg Bros. v. Brooks, $98 \mathrm{~S}$. Ct. 1729, 1738 (1978). This position may be justified because the constitutional regulation of process between debtors and creditors in a commercial setting may intrude on the state's prerogative of defining the "metes and bounds" of a person's interest in property. See idl. at 1735 \& n.10. But see id. at 1740 \& $n .3$ (Sterens, J., dissenting). Such a deference to the state's ordering of private relationships is less justified, howerer, when what is at stake are liberty interests that would be constitutionally protected if the state's involvement were more direct. Cf. Planned Parenthood v. Danforth, 428 U.S. 52, 70 (1976) (state cannot give husband unilateral power to prohibit wife from terminating her pregnancy). This is especially so where the state expressly authorizes a private party to exercise a power the state could not exercise itself. Compare id. at 69 (since state cannot proscribe abortions in first trimester, it cannot delegate this power to any private party) with Flagg Bros. v. Brooks, 98 S. Ct. 1729 (1978) (upholding state statute authorizing private sale of property in satisfaction of warehouseman's lien). Accordingly, it may be argued that the state action in $a$ case like Bartley is simply the enactment of the statute that authorizes parents to admit their children to mental hospitals.

16. U.S. CoNst. amend. XIV, \$ I.

17. Cf. In re Gault, 387 U.S. i, 13 (1967) ("N] the Bill of Rights is for adults alone.").

18. Cf. In re Grimley, 137 U.S. 147 (1890) (individual who cnlisted in military required to serve, even though older than statutory maximum age). Alternatively, it might be argued that a person who consents to restraint is not deprived of liberty within the meaning of the Fourteenth Amendment. Cf. Estelle v. Williams, 425 U.S. 501, $512-13$ (1976) (failure to object to wearing prison garb at trial negates compulsion necessary to establish a constitutional violation). Due process requires, however, that the consent be truly voluntary. Cf. Henderson r: Morgan, 426 U.S. 637, 645 \& n.13 (1976) (guilty plea is voluntary in constitutional sense only if defendant understands both nature of his constitutional protections and nature of charges against him); Schneckloth v. Bustamonte, 412 U.S. 218, 227 29 (1973) ("consent searches" violate Fourteenth Amendment if consent coerced). 
ative of parents to make choices for their children that adults are ordinarily at liberty to make for themselves. The provisions have been challenged on the ground that they deprive the child of his liberty without due process of law. But to the extent that it is legitimate for parents to act as surrogate decisionmakers for their children in this context, the child admitted to a mental hospital by his parents is no more deprived of his liberty without due process of law than would be an adult who voluntarily admits himself. Consequently, the fundamental issue in these cases is whether it is within the scope of the state's constitutional power to sanction a parent's authority over the psychiatric hospitalization of his children.

This issue might be approached in two different ways. First, parental admission statutes could be viewed as delegating power from the state to the parents. If the state had moved directly to confine the child to a mental hospital, the child would have been entitled to notice and a hearing before an impartial decisionmaker. ${ }^{19}$ Parental admission viewed as a delegation of state power is simply an alternative to this: a different procedure but a form of civil commitment nonetheless. Whether the alternative preserves the due process rights of the child depends, initially, on whether the delegation of this decisionmaking power to the child's own parents is proper by constitutional standards. 20 This, in turn, depends on the legitimate scope of the decisionmaker's authority. ${ }^{21}$ Resolution of these issues-who the decisionmaker may be and what the limits on his power are-is a prerequisite for answering the ultimate question of whether the decisionmaking process strikes the appropriate balance between the competing interests involved. ${ }^{22}$ Thus, when viewed as a delegation of state power, parental admission of children to mental hospitals raises questions of procedural due process that can be resolved only after the limits of parental authority over children have been defined. ${ }^{23}$

19. See, e.g., Doremus v. Farrell, 407 F. Supp. 509, 517 (D. Neb. 1975).

20. Cf. Morrissey v. Brcwer, 408 U.S. $471,485-86$ (1972) (parole officer may not act as decisionmaker for parole revocation).

21. Compare Hortonville School Dist. v. Hortonville Educ. Ass'n, 423 U.S. 482, 495.96 (1976) (discharge of striking teachers by school board did not violate due process clause because board's action was policymaking, not merely disciplinary, decision) with id. at 198-99 (Stewart, J., dissenting) (board would be improper decisionmaker if its authority under state law were limited to imposing reasonable sanctions under the circumstances).

22. See Mathews v. Eldridge, 424 U.S. 319, 335 (1976) (stating balancing test for procedural due process).

23. The same inquiry is crucial to resolving the question of state action for children aclmitted by their parents to prisate mental hospitals. According to currently accepted theory, such private conduct would constitute state action only if the parents were excrcising what is traditionally an exclusivelv governmental function. See note 14 supra. 
Alternatively, analysis might begin with the proposition that the primary responsibility for childrearing rests with the parents, not the state. ${ }^{24}$ The statutes would then be viewed as an effort by the state to endorse, clarify, or reinforce a power parents had independently of a legislative grant. The state's power to support the institution of parental authority against the liberty of the child is not, however, absolute. Because children, as well as adults, have constitutional rights, there are limits on the state's power to authorize parents to make decisions for their children, especially in matters that affect the child's fundamental liberty. ${ }^{25}$ Legislative endorsement of parental power that exceeded those limits would, accordingly, violate the substantive rights of the child. ${ }^{26}$ Thus, whichever approach one adopts, it remains necessary to establish the constitutional limits on the state's power to support the institution of parental authority against the liberty interest of children. ${ }^{27}$

In the context of childrearing, however, what is traditionally an exclusive function of the state depends on what is outside the legitimate scope of parental authority. Thus, in this case, the threshold question of state action is not wholly separable from the merits.

24. See Wisconsin v. Yoder, 406 U.S. 205, 232 (1972).

25. See Planned Parenthood v. Danforth, 428 U.S. 52, 74-75 (1976).

26. In Moore v. City of East Cleveland, 431 U.S. 494 (1977), the Court reaffirmed the vitality of substantive due process analysis, although individual justices differed on the scope of protection afforded. Compare id. at 502-04 (plurality opinion of Powell, J.) with id. at 536-37 (Stewart, J., dissenting) and id. at 548-50 (White, J., dissenting). However, cases involving a child's rights against his parents (or, more preciscly; his right to be free from legislatively sanctioned parental control) present issues more complex than those in other cases involving constitutionally protected aspects of family life. Most often in such cases, the issue is whether the state may interfere with or regulate the institution of the family, see Moore v. City of East Cleveland, 431 U.S. 494, 499 (1977), whereas in Bartley the issue is whether the state may support the institution of the family in a way that subjects one of its members to a "massive curtailment of liberty." See note 4 supra. This case is also more complex because there is not only a claim of an individual against the state but also a conflict between two protected liberty interests-that of the parent and that of the child. Such cases are rare, but they do arisc. Sec Smith r. Organization of Foster Families, 431 U.S. 816, $842-47$ (1977) (liberty interest of natural parents is supcrior to arguable liberty interest of foster parents); cf. Roe v. Wade, 410 U.S. 113, 1:36-59 (1973) (holding fetus not a person and thereby avoiding conflict of rights between mother and fetus).

Nevertheless, the basic structure of substantive due process analysis is the same: whether the action of the state is consistent with the history, tradition and basic values of the nation. See Moore v. City of East Cleveland, 431 U.S. 494, 503 (1977) (plumality opinion). See generally Perry, Abortion, The Public Morals, and the Police Power: The Elhicul Function of Substantive Due Process, 23 U.C.L.A. L. REv. 689, 707-23 (1976); Wellington, Common Law Rules and Constitutional Double Standards: Some Notes on Adjudication, 83 YALE L.J. 221, $277-311$ (1973). In assessing the substantive duc process right at issuc in cases like Barlley, three factors are most important: the extent to which parental power over children in similax contexts was protected at common law; the extent to which that power has been protected as statutory and decisional law has evolved; and the extent to which parental authority in this context is consistent with the fundamental values of this nation as they exist today. Part II of this Note explores those questions.

27. This issuc was never adcquately addressed by the courts that have dealt with the parental admission of children. To the extent the issuc was discussed at all, the courts 
It was only very recently that the Supreme Court first addressed directly the issue of parental authority in situations of conflict between the parent and the child, rather than between the parent and the state. In Planned Parenthood v. Danforth, ${ }^{28}$ the Court held that a parent may not exercise "an absolute, and possibly arbitrary, veto" over his child's decision to have an abortion. ${ }^{29}$ When Danforth is read in conjunction with its companion case, ${ }^{30}$ however, it is quite clear that a majority of the Court was prepared to accept some form of parental

in the three main cases reached different conclusions about the role parents should play in the psychiatric hospitalization of their children.

In Bartley itself, parental admission was treated as a waiver of the child's "personal constitutional rights," $402 \mathrm{~F}$. Supp. at 1047-48, but the court did not identify precisely what rights were purportedly being waived. And, in determining the procedural rights of the child, the special status of the parent-child relationship was hardly discussed.

Another of the three main cases also relied on the idea of waiver. See In re Roger S., 19 Cal. 3d 921, 929-31, 569 P.2d 1286, 1290-02, 141 Cal. Rptr. 298, 302.04 (1977). The court discussed whether parents might waive their children's "due process rights," a phrase which the court seemed to define as the set of particular rights that a child would have had in a civil commitment procceding against him. The court concluded that parents may not waire these rights and seemed to infer from this that parents could not authorize the psychiatric hospitalization of their children as part of their general parental authority. Simply put, the argument scems to have been that the state could not hospitalize the child without an adversarial hearing and that, therefore, parents could not do so either. The court assumed, without offering a justification, that there is no constitutionally significant difference between a state's decision to hospitalize a child and a similar decision by a parent. Thus, although the Roger $S$. case did limit a parent's power to authorize his child's psychiatric hospitalization, it offers little useful analysis. See id: at 930, 569 P.2d at 1291, 141 Cal. Rptr. at 303.

The question of parental authority was most explicitly discussed in J.L. v. Parham, 412 F. Supp. 112, 137-39 (M.D. Ga. 1976), prob. juris. noted, 431 U.S. 936 (1977), set for reargument, $98 \mathrm{~S}$. Ct. 761 (1978) (No. 75-1690), but in a way that left important questions unresolved. The court suggested that parental authority does not extend to psychiatric hospitalizations that are arbitrary or not "genuinely necessary," $i d$. at 138, but gave insufficient guidance about what those terms might mean. See id. Second, although the court held that parental authority in this context cannot be unchecked, id. at 139, it gave scant indication of what might be adequate checks on parental power short of total abrogation. See id. at $139-40$.

These three courts disagreed on important matters. Bartley, 402 F. Supp. at 1049, and Roger S., 19 Cal. 3d at 937-38, 569 P.2d at 1296, 141 Cal. Rptr. at 308, held that due process required a hearing before an impartial decisionmaker. Parham would not go that far. $412 \mathrm{~F}$. Supp. at 138-40. Roger $S$. suggested that the case would be different for children less than 14 years old, but did not explain why, 19 Cal. 3d at 931, 569 P.2d at 1292, 141 Cal. Rptr. at 304; the other two drew no such distinction. Finally, although each court achnowledged some boundary between constitutionally permissible and impermissible exeicises of parental authority in this context, there was no consensus about where that botundary should be. Compare Roger S., 19 Cal. 3d at 930, 569 P.2d at 1291, 141 Cal. Rptr. at 303 (no hespitalization unless mentally ill and no less restrictive alternative), with Barlley, $402 \mathrm{~F}$. Supp. at 1053 (110 hospitalization unless "in need of institutionalization") and Parham, 412 F. Supp). at 138 (110 unnecessary or arbitrary admissions; mental hospitals camnot be used as a "dumping ground" for unwanted children). No case discusses directly whether parents may hospitalize their children solely to preserve the psychological wellbeing of other family members, even though this is not an infrequent occurrence, sec Ellis, Voluntecring Children: Parental Commilment of Minors to Mental Institutions, 62 C U.IF, L. Rev. 810, 857.6? (1974).

28. 498 U.S. 52 (1976).

29.) Id. at 74 .

30. Bcllotti v. Baird, 428 U.S. 132 (1976). 
control over such decisions. ${ }^{31}$ The Court left unresolved precisely what forms of non-absolute control are constitutionally permitted and what limits, if any, the Constitution imposes on the factors a parent might consider in exercising this authority. ${ }^{32}$ More importantly, neither in Danforth nor in any subsequent case, has the Court formulated any general account of parental authority or clearly articulated guidelines for determining the circumstances in which it ceases to be legitimate.33

\section{The Constitutional Scope of Parental Authority}

Resolving the issue raised in Bartley and like cases requires a shift in focus from children's rights to parental authority and, in particular, to the constitutional limits on its scope and exercise. These limits can be derived from the underlying rationales for state support of that authority in the first instance: ${ }^{34}$ if the general justifications do not warrant a particular application, then the state is without power to make the parent's consent legally binding on the child.

Five justifications are most often advanced to support parental authority. They may for convenience be termed social pluralism, social order, parental privilege, family autonomy, and child's welfare. Once each of these proffered justifications has been considered, the constitutional limits on a parent's power to admit his child to a mental hospital will emerge.

\section{A. Social Pluralism}

It is a "fixed star in our constitutional constellation," especially with respect to the education of children, that the state shall not impose an orthodoxy "in politics, nationalism, religion, or other matters of opinion." 35 And, especially in matters that relate to families and

31. See id. at 147-48; Planned Parenthood v. Danforth, 428 U.S. 52, 75 (1976); id. at 90-91 (Stewart, J., concurring); $i d$. at 102-05 (Stevens, J., dissenting in part).

32. See Bellotti v. Baird, 428 U.S. 132,148 (1976).

33. Compare Planned Parenthood v. Danforth, 428 U.S. 52, $72-74$ (no absolute parental control over child's abortion) and Carey v. Population Servs. Int'l, 431 U.S. 678, 691-94 (1977) (plurality opinion) (alternative holding) (parents may not absolutely control child's access to contraceptive devices) with id, at 705-07 (Powell, J., concurring in judgment) (parents may control child's access to contraceptive devices) and Ginsbers v. New York, 390 U.S. 629, 636-39 (1968) (parent may control child's access to sex-related material, even though state sanction of similar controls on adults would violate First Amendment).

34. Cf. Moore v. City of East Cleveland, 431 U.S. 494, 504-06 (1977) (Powcll, J., plurality) (looking to purposes for which familics are brought together to fix limits on state's power to regulate extended family); Poe v. Ullman, 367 U.S. 497, $552-53$ (1961) (Harlan, J., dissenting) (arguing that the inherent features of institution of marriagc set limits on state's power to regulate marital relations).

35. West Virginia State Bd. of Educ. v. Barnctte, 319 U.S. 624, 642 (1949); accord, Epperson v. Arkansas, 393 U.S. 97, 103-06 (1968) (dictum) (religious orthodoxy in classroom). 
childrearing, the Constitution also disfavors state practices that threaten to impose on all a single conception of a worthwhile way of life. ${ }^{36}$ The institution of parental authority, by fragmenting decisions about the goals and methods of childrearing, serves to militate against such an orthodoxy. This, historically, has been part of its rationale ${ }^{37}$ and is today one reason for treating parental authority, when asserted against the state, as a constitutional right. ${ }^{38}$ It is therefore not surprising that the Supreme Court has acted more readily to protect parental authority against state intrusion when the threat to social pluralism has been acute. ${ }^{39}$

It has been contended that judgments of social value are implicated in the diagnosis of mental illness and in the decision of whether a person ought to receive treatment in a mental hospital. ${ }^{40}$ To the extent

36. See Moore v. City of East Cleveland, 431 U.S. 494, 506 (1977) (plurality opinion); id. at 508 (Brennan, J., concurring) ("The Constitution cannot be interpreted ... to tolerate the imposition by government upon the rest of us of white suburbia's preference in patterns of family living"); Wisconsin v. Yoder, 406 U.S. 205, 222-24 (1972) (state's compulsory education law cannot be predicated on view that religious order seeking to isolate itself from worldly influences is " 'wrong' "); Pierce v. Society of Sisters, 268 U.S. 510, 535 (1925) (states have no general power to standardize children); cf. United States Dep't of Agriculture v. Moreno, 413 U.S. 528, 534-35 (1973) (no legitimate governmental interest in prerenting "hippies" from participating in federal food stamp program). But see Wisconsin v. Yoder, 406 U.S. at $215 \cdot 16$ (to be constitutionally protected, way of life must be rooted in religious belief). See generally Wilkinson \& White, Constitutional Protection For Personal Lifestyles, 62 CORNel. L. REv. 563 (1977) (discussion of the extent to which individual's choice of lifestyle is or ought to be constitutionally protected).

37. See $1 \mathrm{~J}$. Bentham, Theory of Legislation 254 (Boston 1840).

38. See Smith v. Organization of Foster Families, 431 U.S. 816, 842-44 (1977) ('[T]he importance of the familial relationship, to the individuals involved and to the society, stems from the emotional attachments that derive from the intimacy of daily association, and from the role it plays in 'promot[ing] a way of life' through the instruction of children ... .") (citation omitted); Wald, State Intervention on Behalf of "Neglected" Children: A Search for Realistic Standards, 27 STAN. L. REv. 985, 991-93 (1975) (advocating greater deference to parental authority on social pluralism grounds).

39. Compare Wisconsin v: Yoder, 406 U.S. 205 (1972) (invalidating state compulsory cducation law as applied to Amish children) and Pierce v. Society of Sisters, 268 U.S. 510 (1925) (invalidating state law requiring parents to send their children only to public schools) with Prince v. Massachusetts, 321 U.S. 158 (1944) (upholding statute prohibiting strect solicitation by children as applied to Jehovah's witness distributing religious literature). The Court in Yoder noted especially that the statute as applied "substantially interfer[ed] with the religious development of the Amish child and his integration into the way of life of the Amish faith community" and "carrie[d] with it a very real threat of undermining the Amish community and religious practice." 406 U.S. at 218. Enforcement of the statute in Prince, however, posed no such threat to the Jehovah's Witnesses' way of life; the Court in Prince took pains to note that its holding left parents free to accomplish the religious training and indoctrination of their children by all means "except the public proclaiming of religion [by their children] in the streets." 321 U.S. at 171. More importantly, in Yoder and Pierce but not in Prince the effect of a holding in favor of the state would have been to compel children to confront daily a set of religious and social values antagonistic to those that their parents sought to foster.

40. See, e.g., Szasz, Psychiatric Classification as a Strategy of Personal Constraint, in Ijeology axd INsanity 210 (1970); Ginsberg, Book Review, 54 Child WVelfare 721, 724 (1975) (mental health programs involving children "raise profound questions of what is 
this is true, parental authority with respect to psychiatric hospitalization, like parental authority for religious or secular education, ${ }^{41}$ is constitutionally protected against intrusion by the state. Yet where, as here, the conflict under consideration is between parents and their children, the social pluralism rationale offers little direct guidance. Although a rule favoring parents over the state will always be a bulwark against a state-imposed orthodoxy of social values, a rule favoring: parents over their children may or may not have that effect. The goal of social pluralism might just as well be advanced by allowing children to decide for themselves whether they ought to seek treatment in a mental hospital. The state's interest in safeguarding the diversity of social values thus does not justify state sanction of parental authority over the psychiatric hospitalization of children.

\section{B. Social Order}

Historically, the law recognized society's interest in having children reared so that as adults they would be economically self-sufficient and would conform their conduct to society's norms. ${ }^{42}$ Parents, according to one court, were ordinarily entrusted with this task "because it [could] seldom be put into better hands,"43 but they were subject to state supersession if they failed.44 Parents are still, to some extent, viewed as child-socialization agents of the state. ${ }^{45}$

a good life, what are the acceptable limits of human behavior, and what are the boundaries between conformity and freedom"). See generally H. KAPLAN, supra note 11, at 31-33, $71-75$ (1972) (reviewing empirical literature).

41. There is language in Wisconsin v. Yoder, 406 U.S. 205 (1972), suggesting that parental authority over the education of children is constitutionally protected only when state regulation intrudes on the religious freedom of established religious groups. See id. at 215.16, 234-36. This is not, however, consistent with prior holdings of the Court. See Pierce v. Society of Sisters, 268 U.S. 510, $534-35$ (1925); Meyer v. Nebraska, 262 U.S. 390 (1923). More recently, the "parents' rights" aspect of Yoder-rather than the "free exercise" aspect-has been re-affirmed. See Moore v. City of East Cleveland, 431 U.S. 494, 503 n.12 (1977) (plurality opinion).

42. See Roth v. House of Refuge, 31 Md. 329 (1869); Ex parte Crouse, 4 Whart. 9, 11 (Pa. 1839); 2 J. Kent, Commentarues on Americal Law 195 (5th ed. New York 1844) (Ist ed. New York 1827).

43. Ex parte Crouse, 4 Whart. 9, Il (Pa. 1839); accord, People ex rel. O'Connell v. Turner, 55 Ill. 280, 284.85 (1870).

44. See, e.g., Milwaukee Indus. School r. Supervisors of Milwaukee County, 40 Wis. 328, 337-39 (1876) (neglect statute); Ex parte Crouse, 4 Whart. 9 (Pa. 1839) (neglect statute) (leading case); I Children and Youth in AMeric.s $39-42$ (R. Bremner cd. 1970) (colonial Massachusetts legislation authorized state intervention to assure proper cducation of children by parents). See generally Rendleman, Parens Patriae: From Chancery to the Juvenile Court, 23 S.C.L. REv. 205, $211-47$ (1971); Thomas, Child Abuse and Neglect Part I: Historical Overview, Legal Matrix and Social Perspectives, 50 N.C. L. REv. 293, 299-322 (1972).

45. See Wisconsin v. Yoder, 406 U.S. 205, 224-227 (1972) (dictum) (state supersession of parental authority unjustified where parents succeed in instilling qualities of industry, self-reliance, and good citizenship); Mancino v. Webb, 274 A.2d 711, 712 (Del. Super. Ct. 
Psychiatric hospitalization has been characterized as a mechanism that protects the social order by removing from society those whose behavior violates social norms but who are not amenable to ordinary forms of social control. ${ }^{46}$ For adolescents ${ }^{47}$ and near-adolescents-who together constitute the bulk of the non-adult population of mental hospitals ${ }^{48}$-it is especially true that psychiatric hospitalization functions as much to preserve social order as it does to promote the child's mental health. ${ }^{40}$

1971) (parent liable for child's tortious conduct if he knew of child's mischievous disposition and failed to exercise power of control); Shong, The Legal Responsibility of Parents for Their Children's Delinquency', 6 FAM. L.Q. 145, 156-66 (1972).

46. See R. Perrucci, Circles of Madness $16-18$ (1974); T. Scheff, Being Mentally Ill 170.174 (1966); Szasz, supra note 40, at 210. But see Gove, Societal Reaction as an Explanation of Mental Illness: An Evaluation, 35 AM. Soc. REv. 873, 881-82 (1970) (purpose of psychiatric hospitalization is treatment, not social control). Among sociologists there is a continuing debate about which of two theories of mental illness-Scheff's "societal reaction" model or the traditional "psychiatric perspective"-better explains the available data. See Gove, Reply to Imershein and Simons (1976) and Scheff (1975), 41 AM. Soc. REv. 564 (1976); Scheff, Reply to Chauncey and Gove, 40 AM. Soc. REv. 252 (1975). There can be little doubt, however, that social control is at least a part of the underlying rationale and actual practice of psychiatric hospitalization. See In re Sealy, 218 So. 2d 765 (Fla. 1969) (26-year-old committed to mental hospital by parent largely because he had adopted "hippie" lifestyle and behaved in ways parents found objectionable); In re Aslanian, 318 Mich. 55, 27 N.W.2d 343 (1947) (girl committed to mental hospital by father largely because she was "behavior problem" and "sex delinquent"); Developments, supra note 9, at 1232-33. See generally $\mathbf{R}$. Perrucci, supra, at 7-14, 30-32 (historical account of development of mental asylums).

Some theorists contend also that mental illness itself is a myth. See Szasz, supra note 40, at 12. To say that the therapeutic purpose of psychiatric hospitalization is mythical does not imply that it is fictitious, i.e., that mental hospitals serve no therapeutic purpose at all. See T. Scheff, supra, at 25-26. The myth results from society's tendency to overcmphasize the therapeutic element in order to avoid confronting the less noble purposes of psychiatric hospitalization. See, e.g., H. KAPLAN, supra note 11, at 81-82. Historically, myths have served related purposes. See, e.g., Plato, Republic 67 note, 106-07 (F. Cornford trans. 1945) (myth of metals); T. Szasz, The Manufacture of Madvess 4-13 (1970) (witchcraft). In deciding cases involving constitutional rights, courts should make some effort to look behind the myth of psychiatric treatment to those other social goals that the myth attempts to conceal.

47. Although there is no standard definition of this term, adolescence in a psychological sense is generally regarded as beginning at about puberty, see, e.g., I. JosselyN, ADoLESCENCE 5-6 (1971); Kagan, A Conception of Early Adolescence, 100 Daedalus 997, 998 (1971), which ordinarily occurs beween the ages of 11 and 14, J. Conger, AdolescenCE AND Youth 94-95, 102.05 (1973). In this Note, "adolescent" refers to a child who is at least 14 years old.

48. Almost $80 \%$ of nonadults admitted to inpatient psychiatric treatment are 13 to 19 years old; $16 \%$ are between the ages of 6 and 13. See National. INSTITUte of MeNTaL Health, Hospital Inpatient Treatment for Emotionally Disturbed Children: United States, 1971-72, at 41 (Table 8) (Mental Health Facility Res. Ser. A, No. 15, 1974).

49. Approximately two-thirds of those children and adolescents admitted to mental hospitals are diagnosed as "behavior disorders," suggesting that their hospitalization was prompted at least in part by conduct-"like sexual contacts, running away from home, and truancy"-that disturbed their families or other members of their community. Ginsberg, supra note 48, at 16 . Another researcher, who found that most adolescents were admitted to public mental hospitals because they were unmanageable or behaved in ways regarded as inappropriate by others, concluded that psychiatric hospitalization of ado- 
To the extent that parents actually do admit their children to mental hospitals as a method of social control, they are acting in their role of child-socialization agents of the state and are, therefore, subject to the same constitutional constraints as would apply if the state had acted directly. Since confinement in a mental hospital is a deprivation of constitutionally protected liberty, ${ }^{50}$ the state cannot use psychiatric hospitalization to protect the community from refractory and antisocial children without affording those children procedural safeguards against error and caprice.51 Moreover, considering both the purposes and the gravity of the deprivation of liberty involved, it is likely that only an adversarial hearing ${ }^{52}$ before an impartial decisionmaker ${ }^{53}$ would be constitutionally adequate. Consequently, insofar as psychiatric hospitalization operates to promote the state's interest in maintaining social order rather than in promoting the child's mental health, it is not within the scope of choices that parents may constitutionally be allowed to make for their children.

\section{Parental Privilege}

It is not uncommon for parents to seek to express their own personalities through their children. ${ }^{54}$ This interest of parents may serve as

lescents served more to alleviate community and family annoyances than to promote the mental health of the child. Lindsey, Adolescent Pathways to Residential Treatment: The Enforced Expedition, 9 Adolescence 135, 146 (1974); accord, Cohen, Granger, Provence \& Solnit, Mental Health Services, in 2 Issues in the Classification of Children 112 (N. Hobbs ed. 1975) (parents look to mental health system for help in reasserting control over their children); Miller \& Kenncy, Adolescent Delinquency and the Myth of Hospital Treatment, 13 Crime \& Delinguency 38, 40-42 (1966) (empirical study).

50. See p. 189 supra.

51. See Goss v: Lopez, 419 U.S. 565, 581 (1975) (requiring procedural safeguards for temporary suspension from public school for misconduct).

52. See In re Gault, 387 U.S. 1, 27-31, 41, 51 (1967) (in proceeding that may result in finding of delinquency and incarceration of juvenile in restrictive institution, due process requires hearing, right to counsel, and right to confront and cross-examine adverse witnesses); Heryford v. Parker, 396 F.2d 393, 396 (10th Cir. 1968) (reasoning of Gault applies to commitment of juvenile to training school on grounds of mental deficiency).

53. Cf. Morrissey v. Brewer, 408 U.S. 471, 485-86 (1972) (decision whether to revolkc parole cannot be made by' parolee's parole officer).

54. As one authority explained:

Another expectation is that children will be an extension of their parents' lives, particularly the highly valued aspects. They express the parents' faith that life is worth continuing and that there is something in their own lives that should be carried on. Most parents hope that their children ... will show the attitudes and abilities that they are proudest of in themselves. They want to take pride in their children and feel that through their children their lives are extended into future generations. The child is thus a form of immortality and a contribution to the progress of mankind.

Group for the Advaxcement of Psychiltry, The JoYs and Sorrows of Parenthood 33 (1973); see Marks, Detours on the Road to Malurity: A View of the Legal Conception of Growing $U p$ and Letting Go, LAw \& CoNremp. Proß., Summer 1975, at 76, 86; Stoljar, Children, Parents and Guardians, in 4 InTERnirionil Excyclopcon of CoMp.skitive Law \$ 7.1 (Int'l Ass'n Legal Sci. 1973). 
the basis for the claim they advance to have "the power to dictate their [children's] training, prescribe their education and form their religious opinions." "ss To the extent that the law protects this claim of parents, it creates a parental privilege-that is, a prerogative of a parent to rear his child to be a person whose conduct, character, and belief conform to standards of the parent's choosing. ${ }^{56}$ There can be no doubt that this interest of parents, when asserted against the state, is within the scope of liberty protected by the Constitution. ${ }^{57}$ But in situations in which a parent's choice conflicts not with the state but with the preferences of his own child, parental privilege as a justification for parental authority is less deserving of support. ${ }^{58}$

Parental privilege is deeply rooted but not unequivocally protected

55. Pound, Individual Interests in the Domestic Relations, $14 \mathrm{MICH}$. L. REv. 177, 181 (1916); see, e.g., Pierce v. Society of Sisters, 268 U.S. 510, 518 (1925) (argument for Society of Sisters) ("[T]he child of man is his parent's child and not the State's."); Stoljar, supra note 54 , at $\$ 7-94$.

56. This interest of parents might be protected for its own sake, because a parent's interest in "the companionship, care, custody, and management of his or her children" is so precious to the parent that it merits special judicial respect. Stanley $v$. Illinois, 405 U.S. 645, 651 (1972). Alternatively, parental authority might be protected by law as a quid pro quo for the parental duties the law imposes and as an added psychological inducement to assure that those duties are faithfully discharged. See J. Goudstein, A. Freud \& A. Solnit, Beyond the Best Interests of the Child 25 (1973); 2 J. Kent, supra note 42 , at $* 203$. In either case, authority based on this rationale exists for the sake of the parent.

57. See Wisconsin v. Yoder, 406 U.S. 205, 232-34 (1972); Stanley v. Illinois, 405 U.S. 645 , 6.31 (1972); Prince v. Massachusetts, 321 U.S. 158, 166 (1944). Parental privilege is protected to some cxtent under state law as well. See L.A.M. v. Alaska, 547 P.2d 827, 832 n.13 (Alaska 1976) (parental rights include "right to inculcate in the child the parent's moral and ethical standards"); cf. Secretary of Commonwcalth v. City Clerk, 366 N.E.2d 717, 725 (Mass. 1977) (right of parents to select sumame of their children); Paige v. Bing Construction Co., 61 Mich. App. 480, 485-86, 233 X.W. 2d 46, 49 (1975) (dismissing third-party complaint against parents for negligent supcrvision on grounds that court will not review parental methods of supervising children); Roc v. Doc, 29 N.Y.2d 188, 192-94, 272 N.E.2d 567,570 , 324 X.Y.S.2d 71, 74-75 (1971) (discharging father of obligation to support 20 . ycar-old daughter who adopted living situation contrary to father's instruction; court may not substitute its "standards of decorum" for those of parent). This protection is not as extensive as some commentators think it ought to be. See, e.g., J. Goldstein, Medical Cave for the Child at Risk: On Slate Supervention of Parental Autonomy, 86 Yale L.J. 615 (1977); Levine, Cavcal Parens: A Demystificalion of the Child Protection System, 35 U. PITt. L. Rev. I (1973).

58. Defenses of parcntal authority that appear on the surface to be predicated on parental privilege often reveal on closer examination a concern for other social valueslike freedom from state orthodoxy-for which the concept of parental privilege is a convenient surrogate. See Wisconsin v: Foder, 406 U.S. 205, 218-19, 223-24, 232 (1972) (recurrent reference to state imposition of religious values in discussion of state requirement that .Imish parents send their children to public high school); Pierce v. Society of Sisters, 268 U.S. 510, 535 (1925) (conflating parental privilege and social pluralism rationales); J. coldstein, sufma note 57 . at 6.54 .55 (right of parents to choose medical treatment for their children is especially justified where there is no valid, objective standard of proper carc). When detached from the ancillary support of the social pluralism rationale, howcver, the claim of parents to elirect their children's upbringing clicits much less support. See, e.g., id. at (i.j1.52) (approving state supervention of parental authority to avoid death of child who would otherwise have had opportunity for "life worth living"). 
in the American legal tradition. Historically, it was the generally accepted rule that a parent is entitled to the custody and control of his child unless the parent was shown to be unfit. ${ }^{59}$ This had the effect of protecting parental privilege as against other adults and the state. Only a few cases, however, dealt with the scope of parental authority for parents who had not forfeited their rights to custody and control. In those cases, the courts sometimes supported parental privilege ${ }^{80}$ but sometimes did not. 61

The idea that parental authority exists and is exercised for the sake of the parent rather than for the sake of the child, the family, or the community is further undercut by its conflict with more basic moral notions:

It is as a parent, not just as an isolated individual, that a man or woman imposes obligations on children; these grow out of the office or function the parent sustains, not out of mere personal will. When they express merely one will in opposition to another, instead of proceeding from the tie which binds persons together, they violate their own basis. ${ }^{62}$

59. See, e.g., State ex rel. Sharpe v. Banks, 25 Ind. 495, 500-02 (1865) (ordering child delivered to father from custody of maternal grandfather); Milwaukee Indus. School v. Supervisors of Milwaukee County, 40 Wis. 328, 338-40 (1876) (construing child neglect statute so that parent's right to care and custody would not depend on discretion of state officials).

60. See Commonwealth r. Armstrong, 1 Pa. L.J.R. 146, 151-53 (Ct. Q. Scss. Peace 1842) (minister who baptized 17-year-old girl over father's objection had unlawfully interfered with father's prerogative to regulate religious conscience of child); In re Agar-Ellis, $24 \mathrm{Ch}$. D. 317, 319, 329, 331-34 (Ch. App. 1883) (father has right to limit 16-ycar-old daughter's communications with her mother solely to prevent daughter from losing affection for him); cf. $2 \mathrm{~J}$. KeNT, supra note 42, at $* 03 \mathrm{n}$.(c) (approring Armstrong and stating that "parents have the right to direct their children to embrace the religion which they themselves approve.") (cmphasis added).

61. See Commonwealth v. Sigman, 2 Pa. L.J.R. 36, 44-48 (Ct. Q. Sess. 1843) (charge to jury) (once child attains "years of discretion" parent may not interfere with "rights of [religious] conscience" by forcefully removing her from religious ceremony); Commonwealth ex rel. Joseph v: M'Keagy, 1 Ashmead 248, 254-56, 258-60 (Pa. C.P. 1831) (dictum) (father, "vexed" by child's disobedience, may not, under statute, commit him to House of Refuge; "parental authority is limited to what is for the benefit of the child"); Creuze v. Hunter, 30 Eng. Rep. 113, 113 (Ch. 1790) (restraining father from interfering in son's education; Chancellor will "not allow the child to be sacrificed to the views of the father"); cf. In re Agar-Ellis, 24 Ch. D. 317, 328, 333 (Ch. App. 1883) (citing rulc that capricious exercise of parental authority would not be sanctioned by court).

62. J. Dewey, TheORY of the Moral Life 81 (A. Isenberg cd. 1960). This philosophical conception of parenthood has deep roots in the mores of Western civilization. See Stoljar, supra note 54 , at $\$ \$ 7-33$ to $-36,7-41$ to -46 (in both Roman and early Gcrmanic socictics parental authority served social function and was constrained by social norms). See also id. $\$ 7-121$ (absolute right of parent under carly French law to incarcerate child became in 20th century judicially" supervised mechanism for child placement undertaken no longer for sake of parents but only in interests of child). 
It is regarded by many as unjust for one adult to impose his conception of the good life on another ${ }^{63}$ and as demeaning to another's dignity not to respect his choice of his own life plan. ${ }^{64}$ Psychological studies show that at adolescence, children of normal intellect are in this respect substantially like adults: they have the basic cognitive capacities to choose intelligently among competing values and to formulate their own life plans. ${ }^{65}$ So, as applied to adolescents, parental privilege-the prerogative of parents to impose on their children values and styles of life that best express the parents' personalities-is especially hard to justify on moral grounds. These moral considerations derive implicit legal sanction from those court decisions that permit an adolescent to act on his own values over the objection of his parent. ${ }^{.6}$

This capacity for autonomous choice provides the basis for constitutional limits on parental privilege as well. In Planned Parenthood $v$. Danforth, ${ }^{67}$ the Court held that the state could not give parents veto power over their child's abortion. ${ }^{88}$ In considering whether parents might veto their child's abortion decision just because it conflicted with their own moral values or personal interests, the Court said:

[T] he State does not have the constitutional authority to give a third party an absolute, and possibly arbitrary, veto over the decision of the physician and his patient to terminate the patient's pregnancy, regardless of the reason for withholding consent.

....

... Any independent interest the parent may have in the termination of the minor daughter's pregnancy is no more weighty than the right of privacy of the competent minor mature enough to become pregnant. ${ }^{69}$

This suggests that when parental privilege is asserted against a child capable of autonomous choice in a matter that substantially infringes

63. E.g., Frankena, The Concept of Social Justice, in Social Justice 20 (R. Brandt ed. 1962).

61. E.g., J. Rawls, A Theory of Justice 440.41 (1971).

6.5. See p. 206-07 infra.

66. See In re Smith, $16 \mathrm{Md}$. App. 209, 226, 295 A.2d 238, 246 (1972) (parent may not compel 16-ycar-old to have abortion); Buckholz v. Leveille, 37 Mich. App. 166, 171, 194 N.W.2d 427, 429 (1972) (16-year-old may challenge suspension from school for riolating dress code even though parents want him to conform to code and oppose suit); Martin v. Martin, 308 N.Y. 136, 138-39, 123 X.E.2d 812, 812 (1954) (per curiam) (12-ycar-old permitted to attend church of choice and transfer from parochial school over parent's objection). Bul se'e Roc v. Doc, 29 N.Y.2d 188, 194, 272 N.E.2d 567, 570, 324 N.Y.S.2d 71, $75-76$ (197I) (20-ycar-old who violates parent's instructions about where to live forfeits right to parent's financial support).

67. 428 U.S. 52 (1976).

68. Id. at 74 .

69. Id. at 74-75 (emphasis added). 
on the child's basic liberty, it is not constitutionally protected and may well be constitutionally proscribed. When the state is confronted with a clear conflict between parent and child that implicates each of their fundamental values, it may not automatically favor the parent. ${ }^{70}$ Since parental admission of adolescent children to mental hospitals so often presents such a parent-child conflict, ${ }^{71}$ the state may not sanction such exercises of parental authority on the basis of the parental privilege rationale.

\section{Family Autonomy}

The state's interest in preserving the family unit is often cited to justify state sanction of parental authority. ${ }^{72}$ But protecting the family from outside interference is quite distinct from fortifying the family's porver over one of its members. Although constitutional support for the former is clear and well-established, ${ }^{73}$ the constitutional support for the latter is not. Until recently, the Supreme Court avoided addressing this issue; ${ }^{\text {it }}$ when it did discuss it, its conclusions were unclear. ${ }^{\text {is }}$

When a parent, in his role of family governor, exercises authority over the child, his action has a moral basis that the exercise of bare parental privilege lacks. ${ }^{\text {io }}$ But there are other criteria for the moral assessment of social institutions-whether an institution that makes claims against some provides some reciprocal benefit for each of those

70. See Planned Parenthood Ass'n v: Fitzpatrick, 401 F. Supp. 554, 567 (E.D. Pa. 1975); Burt, Developing Constitutional Rights of, in, and for Children, LAw \& ConteMp. РRов., Summer 1975, at 118, 137-38.

71. See pp. 195, 197 supra; pp. 203-04 infra; Ellis, supra note 27, at 859.60.

72. See Commonwealth v. Brashcr, 359 Mass. 550, 557, 270 N.E.2d 389, 394 (1971) (up). holding statute making it a crime for minor to disobey parent or one in loco parentis); Pound, supra note 5.5, at 186-87; Note, Parental Consent Requirements and the Privacy Rights of Minors: The Contraceptive Controversy, 88 H ARv. L. REv. 1001, 1016 (1975).

73. See Moore v. City of East Cleveland, 431 L'.S. 494 , 499 (197i) (intrusive regulation of family subject to careful judicial scrutiny).

74. See Wisconsin v. Yoder, 406 C.S. 205, 237 (1972) (Stcwant. J., concurring); id. at 243-46 (Douglas, J., clissenting in part); Rowan r. Lnited States Post Office Dep't, 397 U.S. 728, 741 (1970) (Breunan, J., concurring).

75. In Planned Parenthood v. Danforth, 428 U.S. 52, 75 (1976), the Count rejected the safeguarding-the-family rationale in one sentence on the grounds that a parental veto of a child's abortion decision could nerer actually strenerthen the fanils unit. But in the companion case, Bellotti $x$. Baird, 428 C.S. 132 (1976), the Court suggested that some statesanctioned influence l)y parents orer the child's abortion decision might be constitutional, id. at 147, provided that consent was not witheld for an impermissible reason, $i d$. at 148 , but specifically reserved judgment on what was permissible and what was not. idl. The Court, thus, left unresolicd whether the effect of a child's abortion decision on family harmony is ever a permissible ground for withholding consent. The lower court, however, stated clearly that it was not. Bellotti v. Baird, 393 F. Supp. 817, 856 (D). Mass. 1975), vacated and remanded, 128 U.S. 132 (1976), on remand, 428 F. Supp. 854, 85.5 (1977).

76. See p. 200 supra. 
whose liberty it restricts, ${ }^{77}$ or whether it makes an equal relative contribution to the good life of each of its participants. ${ }^{78}$ Although family life may often require that some good of one individual be foregone for the well-being of the family as a whole, a family that excessively derogates the interests of one for the sake of the others undermines its own moral basis.

These moral considerations suggest a legal norm. The state need not intervene in every family dispute, ${ }^{\text {i9 }}$ but if it does, it must treat each family member affected as having a distinguishable interest, which is equally entitled to the protection of the state. ${ }^{80}$ And, in particular, where parents solicit or simply avail themselves of the sanction of law to augment their controls over family life, the child's own individual interest must be taken into account. ${ }^{\text {s1 }}$ Therefore, if it is based on the family autonomy rationale, the legitimacy of state sanction of parental authority with respect to a certain class of decisions depends on the consequences of those decisions for family well-being, on what the child is being asked to sacrifice for the sake of his family, and on what he ultimately stands to gain. ${ }^{82}$

Parents sometimes will place their child in a mental hospital not as much for his own sake as for the sake of the family of which he is a part. $^{83}$ The child may actually benefit from this, for the period of

77. See J. Dewey, supra note 62, at 83; Strawson, Social Morality and Individual Ideal, in Readings in Contemporary Ethical Theory 352 (K. Pahel \& M. Schiller eds. 1970), reprinted from 36 PhiLosophy I (1961).

78. See Frankena, supra note 63, at 20; cf. K. BaIer, The Moral PoINT of View 200.03 (1958) (moral rules must be "for the good of everyone alike").

79. E.g., People ex rel Sisson v. Sisson, 271 N.Y. 285, 2 N.E.2d 660 (1936) (per curiam).

80. See Planned Parenthood v. Danforth, 428 U.S. 52, 70 \& n.11 (1976); Reed v. Reed, 404 U.S. $75,76.77$ (1971) (despite "positive value of avoiding intrafamily controversy," probate law that automatically favors futher over mother violates equal protection clause).

81. Sce note 66 supra \& note 95 infre (citing cases).

82. This legal principle makes two implicit assumptions. First, it assumes that the interests of a child can be distinguished from the interests of other family members. This is not alwa!s so. Sece, e.g.. p. 204 infra; Hart v. lbrown, 29 Comn. Supp. 368, 374-75, 289 A.2d 386,389 (Super. Ct. 1972) (welfare of child who is potential kidney donor is not separate from welfare of entire family). Second, it assumes that egalitarian principles apply to families as well as to socicty at large. Although this notion would be embraced by some, e.g. M. Lerner, The Child ANd P.ikest in AMericin Civilizition 8 (1958), it is not a model of family life that is slated by all segments of the community, see D. SCHNEIDER \& R. Smith, Cinss Differences axb Sex Roles in AMerican Kmship and Family Structure $46-47,55-56$ (1973). The constitutional proscription against a state orthodoxy of values, see pp. 194-95 suma, would ordinatily bar state support of one of these models over the other. See Moore v. Cill of East Cleveland, 431 U.S. 494, 499, 506 (1977) (plurality opinion). But once the statc intervencs in an intrafamilial dispute, it must intervene on the side of individual rights.

83. Sre note I suma; Ferleger, Incatcerated Juveniles-Why? The Mental Institutionalization of Jureniles in Jenushlvania, in Record at 215a-19a, Kremens v. Bartley, 431 U.S. 119 (1977) (citing instances from hospital records); M. Gros \& J. Singer, stpra note II, at 122 ("most parents did sec the hospitalization serving an amelionative functione.s.. releiving them of responsibility and of home tensions, and protection of the patient and/or societs"). There is a prima facie distinction between parents acting for the sake of 
separation allows family harmony to be restored making the child's life better when he finally returns home, ${ }^{84}$ but psychiatric hospitalization may also further isolate the child from his family-a risk that increases with the length of hospitalization..$^{85}$ Moreover, this same benefit to family stability could be achieved by placing the child in a facility less restrictive than a mental hospital. ${ }^{86}$ Families benefit from the psychiatric hospitalization of children, however, in another, more subtle way. Often the very fact of labelling the child as mentally ill creates the family benefit, for it places the child in the social role of "scapegoat" for the family's interpersonal difficulties. ${ }^{87}$ But since the stigma of mental illness itself adversely affects the child, ${ }^{88}$ it is doubtful that this road to family tranquillity can be sanctioned by law. Finally, although involuntary psychiatric hospitalization may have direct benefits to the family and ancillary benefits to the child himself, the price the child is required to pay for this is "a massive curtailment of liberty." 89 The state's interest in safeguarding the family unit may be substantial, ${ }^{90}$ but it is not substantial enough to sanction parental authority to place children in mental hospitals who do not need the treatment they provide or who would benefit as well from forms of treatment that less drastically curtailed their freedom. ${ }^{01}$

the state to protect the community from the antisocial behavior of their children and parents acting for the sake of maintaining family integrity or equilibrium, but since the same behavior may have consequences for both the family and the community, psychiatric hospitalization of children may serve both ends simultaneously.

84. See J.L. v. Parham, 412 F. Supp. 112, 134 (M.D. Ga. 1976), prob. juris. noted, 431 U.S. 936 (1977), set for reargument, 98 S. Ct. 761 (1978) (No. 75-1690) (Dr. John P. Fillcy); cf. A. Copeland, Textbook of adolescent Psychopathology and Treitmevt 87-88 (1974) (hospitalization marshalls family support).

85. DeMyer, New Approaches to the Treatment of Very Young Schizophrenic Children, in The Mental Health of the Child 424 (Public Health Ser. Pub. No. 2168, 1971); Flomenhaft, Outcome of Treatment for Adolescents, 9 AdoLEscence 57, 57 (1974); Linnihan, Adolescent Day Treatment: A Community Alternative to Institutionaliaation of the Emotionally Disturbed Adolescent, 47 Aм. J. ORTновsYch. 679, 679 (1977).

86. There are a variety of altemative placements outside the home for emotionally disturbed children, including small group homes and specialized foster parent programs, that impair a child's liberty less than does a mental hospital. See J.L. v. Parham, 412 F. Supp. 112, 122-23 (M.D. Ga. 1976), prob. juris noted, 431 U.S. 936 (1977), set for reargument, 98 S. Ct. 761 (1978) (No. 75-1690) (citing Report of the Study Commission on Mental Health Services for Children and Youth 24 (Georgia Div. Mental Health 1973)). Such placements may be both much less costly than psychiatric hospitalization, see, e.g., id. at 126 (citing Study Commission Report's comparison of hospital and group home costs), and more effective, see Reiger, Changing Concepts in Treating Children in a State Mental Hospital, INT'L J. ChILd Psychother.PY, October 1972, at 89, 107-10 (adrocating creation of specialized treatment homes).

87. See Ellis, suppra note 27 , at $859-60$ (reviewing psychological literaturc).

88. See note 11 supra (citing authoritics).

89. Humphrey v. Cady, 405 U.S. 504, 509 (1972); see pl. $188-89$ supra.

90. See, e.g., S. Katz, When Parents Fall 1-3 (1971) (social function of family); Wilkinson \& White, supra note 36 , at 623.24 (defining state's interest in family).

91. See In re Roger S., 19 Cal. 3d 921, 930-31, 569 P.2d 1286, 1291-92, 141 Cal. Rptr. 298, 303.04 (1977). 
For adolescents, who typically possess the capacity for autonomous choice, ${ }^{02}$ parental authority based on the family autonomy rationale is even more circumscribed. Historically, courts recognized that the choices of a minor who has reached the "age of consent" have a legal status vis-à-vis adults different from those of a child who has not. ${ }^{93}$ In particular, in matters affecting an adolescent's liberty, courts in the nineteenth century would not always allow his parents' choice to bind him..$^{04}$ It is similarly inconsistent with contemporary standards for parents to have the power, unchallengeable by the adolescent himself, to cause or continue his confinement in an institution that drastically restricts his liberty. ${ }^{95}$ Neither the state's interest in maintaining family integrity nor its more particular interest in enhancing parental control over family life is sufficient to justify such exercises of parental power.

\section{E. Child's IVelfare}

The last of the proffered justifications of parental authority is that it serves the child's welfare. ${ }^{96}$ It has been suggested that allowing parents to be the supreme arbiters of their child's fate is justified be-

92. See pp. 206-07 infra.

93. See, e.g., Commonwealth v. Nickerson, 87 Mass. (5 Allen) 518, 527 (1862) (taking minor from one with legal custody constitutes crime of false imprisonment, unless minor of sufficient maturity assents) (by implication); Boundell $v$ : Berryhill, 2 Ind. 613, 615 (1851) (parentless child over fourteen has power to choose own guardian).

94. See, c.g., State ex rel. Baird v. Baird, 18 N.J. Eq. 194, 198-99, 203 (1867) (equity will not enforce father's right to custody of child who has attained age of discretion but " 'will let the child go where he will" "); Respublica r. Keppelc, 1 Yeates 233, 2 U.S. (2 Dall.) 197 (Pa. 1793) (14-year-old clischarged from service to which he had been bound by guardian); $c f$. J. Locke, SEcoNd TReitrise ON Government $\$ 65$ (London 1690) (once child attains "years of discretion" parent can no more "dispose" of his liberty than that of adult).

9j. See, e.g., In re Henry G., 28 Cal. App. 3d 276, 285, 104 Cal. Rptr. 585, 591 (1972) (in incorrigibility action child may raise parental misconduct as defense); Collin v. York, 159 Conn. 150, 267 A.2d 668 (1970) (by next friend, minor may institute suit for release from state training school even though parents oppose suit and would not have instituted it on their own); K.E.S. v: Georgia, 134 Ga. App. 843, 216 S.E.2d 670, 672.73 (1975) (mother who initiates incorrigibility procecdings cannot then waive child's right to counsel). These cases reflect the growing recognition of the adolescent's autonomy from parental control. Compare, e.g., In re Sippy, 97 A.2d 455, 456-57 (D.C. 1953) (in procecding to commit child to "psychiatric school," mother's attorney may not represent child) with Rule v: Geddes, 23 App. D.C. 31 (D.C. Cir. 1904) (17-ycar-old girl "having no right . . . to select her own course of life, ha[s] no legal right to be heard in [incorrigibility] proceedings"); compare Commonwealth $\checkmark$. Brasher, 359 Mass. 350,270 N.E.2d 389 (1971) (upholding colonial statute that imposed criminal sanctions against "stubborn children") (Mass. ANN. L.ws ch. 272, \$ 5.3 (Michic/Law. Co-op 1968)) with 1973 Mass. Acts ch. 1073, § 20 (making same statute inapplicable to "stubborn children" and "runaways").

96. See, e.g., United States v. Green, 26 F. Cas. 30 (C.C.D.R.I. 1824) (No. 15,256) (Story, J.); Stoljar, supre note 54 , at $\$ 7-98$ (laws in (iermany and Great Britain regard child's welfare as primary justification for parental authority). 
cause it is conducive to the child's long term psychological health. ${ }^{97}$ More commonly, parental authority is defended on the ground that someone must choose for children since they lack the capacity to choose for themselves; parents are assigned this role because they are presumed to be better able to perform the task than anyone else.98

The legitimacy of parental authority based on the child's welfare rationale depends primarily on the child's capacity to choose for himself. This capacity will vary with age. Parental authority over preadolescents is justified because the assumption that children are not competent to make their own choices is, as applied to them, generally correct. ${ }^{99}$ Since, however, parents under this rationale are presumed to act as guardians of the child's interests, parental authority would lose its underlying legitimacy if exercised for purposes unrelated to the child's welfare $^{100}$ or in ways that create for the child a substantial risk of harm. ${ }^{101}$

For the adolescent, the situation is more complex. Psychologists agree that about the time of adolescence a major transformation occurs in the quality of a child's thought. ${ }^{102}$ As a consequence of a shift to what is called formal operational thought, ${ }^{103}$ the youngster is capable of abstract, logical, and scientific thinking, ${ }^{104}$ which enables him to see the practical possibilities of real-life situations ${ }^{105}$ and to anticipate and evaluate the consequences of his own conduct. ${ }^{106}$ Simultaneously, or

97. J. Goldstein, A. Freud \& A. Solsit, supra note 56, at 25; J. Goldstein, supra note 57, at 649-50.

98. See, e.g., In re Faust, 239 Miss. 299, 305-07, 123 So. 2d 218, 220-21 (1960); 1 J.

Bentham, supra notc 37, at 248-49; J. Goldstein, supra note 57, at 645-47.

99. See p. 207 infra.

100. See $1 \mathrm{~J}$. Benthim, supra note 37, at 248-49, 252-53; J. Locke, supra note 94, $\$ s 64-65$.

101. See, e.g., Wisconsin v. Yoder, 406 U.S. 205, 233.34 (1979); In re Karwath, 199

N.W.2d 147. 150 (Iowa 1972).

102. Sec, e.g., D. El.kind, ChildkfiN and Adoliscents 99-104 (2d ed. 1974); B. INHeldeR

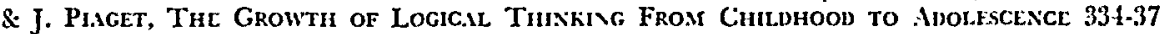
(1958) (seminal work in ficld); E. Peez, The Nature of Adolrscent Judgacnt 45-48, 15154 (1971); Kohlberg \& Gilligan, The Adolescent as a Philosopher: The Discovery of the Self in a Poslconventional World, 100 D.tedalus 1051, 1059-65 (1971).

103. See Elkind, Cognilive Development in Adolescents, in Understanding Adolescence 139 (J. Adams ed. I968).

104. See B. INheider \& J. Piaget, sutja note 102, at 251-55, 335; Adelson, The Development of Ideology in Adolescence, in Adolescence in THE LIFE CrCLE 67-68 (S. Dragastin * G. Elder eds. 1975); Elkind, supra note 103, at 144-48.

105. See, e.g., D. ElK1ND, supra note 102, at 100-01; E. Pefl, supra note 102, at 20-22, 31-39.

106. See Readings in Adollscent Drvelopmpxt and Beftuwor 85 (J. Hill \& J. Shelton eds. 1971). No studies substantiate this point directly; but it is readily inferred from other evidence.

With the emergence of formal operational thought, or what Pecl calls the capacity to explain, comes the capacity to use concepts of probability and to predict. B. INHeLver \& J. P1.selt, supha note 102, at 323-24; E. P1.t., supra note 102, at 30-35. The adolescent, ats 
perhaps as a consequence of the same underlying process, the individual acquires an appreciation for the social ramifications of individual conduct, ${ }^{107}$ and a capacity to formulate his own personal and social ideals. ${ }^{108}$

When a person makes choices after having identified the likely consequences for himself and others and having evaluated those alternatives in light of an overall life plan, he has chosen intelligently, even if unwisely from someone else's point of view. By this criterion, the psychological evidence shows that the typical adolescent will have acquired a basic capacity for intelligent choice by about fourteen years old. ${ }^{109}$ The right of a child at that age to make certain choices for

compared with his junior, can see aspects of a situation beyond what is actually presented, see note 105 supra, and shows a greater capacity to look into the future, see Adelson, supra note 104, at 68; Adelson, The Political Imagination of the Young Adolescent, 100 Daedalus 1013, 1017.18 (1971). He is, in short, less wedded to the "here and now." Elkind, supra note 103, at 152. Finally, the pre-adolescent's mind "as it ponders politics" has little sense that benefits to some give rise to costs for others, and that this capacity occurs only among "older adolescents." Adelson, supra note 104, at 69. Adelson does not make it clear when the capacity to engage in "cost-benefit" reasoning in a less global context appears, but it is consistent with some of his earlier results that this change occurs in early adolescence or just before. See Adelson \& O'Neil, Growth of Political Ideas in Adolescence: The Sense of Communily, in CONTEMPORIRY Issues IN ADOrescent DeveLOrMENT 61 (J. Conger ed. 1975).

107. See Adelson, supra note 104, at 67.70 (updating earlier study); Adelson \& O'Neil, supra note 106, at 57-62.

108. See, e.g., D. ElKind, supra note 102, at 103 (adolescent can construct ideals and conceive of ideal families, religions, and societies); Kohlberg \& Gilligan, supra notc 102, at 1066-72 ("It is in adolescence, then, that the child has the cognitive capability for moving from a conventional to a postconventional, reflective, or philosophic view of values and society:"); Okun \& Sasfy, Adolescence, The Self-Concept, and Formal Operations, 12 ADolescence 373, $377-78$ (1977) (capability to formulate self-concept is concomitant with formal operational thought, which comes only in adolescence); Piaget, The Relation of Affectivity to Intelligence in the Mental Development of the Child, 26 BuLL. MENNINGER Cunic 129, 137 (1962) (with formal thought, individual acquires capacity to play role in society that he, himself, has chosen and to group and regulate the whole of his values).

109. See B. Inhelder \& J. PIAget, supra note 102, at 335.47 (formal operational thought achieved between 11 and 15 years old); E. PEEL, supra note 102, at 20-22, 31-33, 36-38, 45.48 (citing studies showing that capacity for "explanatory judgment" is achieved by most children by about 141/2 years old); Adelson \& $O^{\prime}$ Neil, supra note 106, at 69 . But see Kohlberg \& Gilligan, supra note 102, at 1065 (most people do not achieve highest levels of formal operational thought until 15 years or older). This evidence does not show that a 14-year-old's judgment will be like an adult's in all respects, but it does indicate that he will probably have a basic capacity to make choices for himself.

There is support for the claim that the judgment of a younger adolescent is not mature, but by age 16 these forms of adolescent immaturity have generally passed. See $D$. Elkind, supra note 102, at 90-94 (carly adolescent is preoccupied with others' view of him but this "egocentrism" diminishes by 15 or 16); Adelson, supra note 106, at 1025-26 (social assessments of 13-year-olds tend to be dogmatic, inflexible, and simplistic, but 14- to 15 year-olds are more critical, tentative, and pragmatic); Elkind, supra note 103, at 152-53 (younger adolescent is hypercritical of disparity between his ideals and reality but is less militant and more understanding later on); Query, The Influence of Group Pressures on the Judgments of Children and Adolescents-A Comparative Study, 3 ADOLESCENCE 153, 155 (1968) (tendency for younger adolescents' judgments to be influenced by group pressure, but by 16 years' old this tendency not significantly different from that of adult). In addition, by 15 or 16 years' old, the arerage adolescent in an industrial society will 
himself was recognized historically, ${ }^{110}$ and is reflected in the law today. ${ }^{111}$ In view of both the empirical evidence and the legal precedents, the general presumption that children are not competent to choose for themselves should be reversed for children who are at least fourteen years old. ${ }^{112}$ As applied to them, the child's welfare rationale for parental authority loses most of its force.

This does not, of course, imply that the law must treat the choices of a fourteen year old exactly as it treats the choices of an adult, for the adolescent's judgment may not yet be mature in all respects. ${ }^{113}$ Parents therefore still may have some role to play. ${ }^{114}$ To specify what

have achieved all the basic cognitive capacities of an adult. See, e.g., President's Science Advisory Commitree, Youth: Transition to Adulthood 99 (Panel on Youth) (1974); $D$. ElkiNd, supra note 102, at 94; Adelson \& O'Neil, supra note 106, at 69.

110. See, e.g., Boundell v. Berryhill, 2 Ind. 613, 615 (1860) (parentless child at least 14 years' old may elect suitable person to be his guardian); The Queen v. Howes, 121 Eng. Rep. 467 (K.B. 1860) (court will not order 14-year-old boy or 16-ycar-old girl returned to father's custody against child's wishes); cf. 4 W. Blackstone, Commentaries *22-23 (child at 14 presumed capable of criminal intent). But see State ex rel. Herrick v. Richardson, 40 N.H. 272, 277-78 (1860) (in custody dispute between parents, preferences of 14-year-old will be weighed, but will not control).

111. See, e.g., In re Roger S., 19 Cal. $3 \mathrm{~d}$ 921, 931, 569 P.2d 1286, 1292, 141 Cal. Rptr. 298, 304 (1977) (14 appropriate age to assert "due process rights"); Ferrie v. Trentini, 111 Conn. 243, 149 A. 664 (1930) (interpreting what is now CoNv. GEN. STAT. $\$ 45-46$ (1977)) (parentless child at least 14 years old may select own guardian); Peacock v. Adams, 230 Ga. 774, 199 S.E.2d 254 (1973) (in custody dispute between parents, choice of child at least 14 years old is controlling); Buckholz r. Leveille, 37 Mich. App. 166, 170, 194 N.W.2d 427, 429 (1971) (child 14 years of age or older may sue without parental consent or eren against parents' wishes); ALA. Cone tit. $22 \$ 22-8-4$ (1977) (minor 14 sears old or older may give effective consent to medical, dental, or mental health care); PA. ANN. ST.1T. tit. 50, \$7201 (Purdon Supp. 1977) (person 14 years old or over may consent to psychiatric hospitalization). But see Sicgel \& Hurley, The Role of the Child's Preference in Custody Proceedings, 11 FAM. L.Q. 1, 17-31 (1977) (in many states, preference of child 14 or older is not controlling); Wilkins, Children's Rights: Removing the Parental Consent Barrier to Medical Treatment of Minors, 1975 ARIz. ST. L.J. 31, 39 (15 is age at which courts will find minor mature enough to consent to his own medical treatment).

112. Some adolescents will not in fact be eren minimally competent to choose for themselves, but eren they are entitled to the same rights as other adolescents until the presumption of competence to choose is rebutted. Nor should the presumption of competence be reversed simply because the adolescent is alleged to be mentally ill. The mental illness of an adolescent may affect, but it does not undermine, his capacity to choose. See Hayden, Nasby \& Davids, Interpersonal Conceptual Structures, Predictive Accuracy, and Social Adjustment of Emotionally Disturbed Boys, 86 J. ABNorm.1L Psyci1. 315, 319 (1977); Platt, Spivack, Altman, Altman \& Peizer, Adolescent Problem-Solving Thinking, 42 J. Consclting \& Cuinical. Psych. 787, $791-92$ (1974) (cmotionally disturbed adolescents, as compared with normal counterparts, show diminished capacity to resolve interpersonal problems, but show no difference in capacity to solve non-personal problems, to perceive causes and consequences of social behavior, or to deal with their own emotions); Reker, Interpersonal Conceptual Structures of Emotionally Disturbed and Normal Boys, $83 \mathrm{~J}$. Abnormal Psych. 380, 384-85 (1974). Morcover, even if mentally ill adolescents were less able to make choices for themselves than normal adolescents, that would be legally relevant only after an adjudication of mental illness.

113. Sec note 109 supra.

114. Se' Carev v. Population Servs. Int'l, 431 U.S. 678, 708 (1977) (Powell, J., concurring); Planned Parenthood v. Danforth, 428 U.S. 52, 95 (1976) (White, J., dissenting); 1 W. Br.ackstonr, Commentaries * 453 (parental consent protects children from "the snares of artful and designing persons"). 
that role is, however, will require more detailed analysis tailored to a particular context. The result of that analysis may not simply be a specification of when parents may choose for their adolescents and when they may not. Rather, the result may be an attempt to apportion decisionmaking power between the adolescent, the parent, and the state. ${ }^{115}$

\section{Due Process Constraints on Parental Authority}

When a claim is made that an exercise of parental authority over children violates the child's right to due process of law, that claim must be assessed in light of the special status of the parent-child relationship. As discussed in Part II, the basic rationale for parental authority combined with the peculiarities of psychiatric hospitalization place substantive constitutional limits on a parent's power to place his child in a mental hospital. These limits will vary depending on the age and psychological development of the child. The state may authorize parents to place their pre-adolescent children in mental hospitals, but it may do so only when the parents have a legitimate reason for their action. If the state chooses to sanction parental authority explicitly by legislation, it must also provide procedural safeguards against abuse. For adolescents, however, state sanction of parental authority over psychiatric hospitalization is not justified. The state might establish procedures whereby an adolescent and his parents both participate in a decision about the child's psychiatric hospitalization, but such procedures must safeguard the adolescent's capacity and right to autonomous choice. ${ }^{110}$ These general propositions set the background for defining in more detail what process is due.

\section{A. Pre-adolescents}

With respect to pre-adolescents, parents may be-and in light of other considerations ought to be-given broad discretion. Although the preadolescent may well have preferences, he is not yet capable of making an intelligent choice; his parents may be authorized to act as his surrogate decisionmaker. ${ }^{117}$ And because the pre-adolescent is not yet able

115. See p. 214 infra.

116. The constitutional right of privacy applies to minors as well as adults, Carey $v$. Population Servs. Int'l, 431 U.S. 678, 692-93 (1977) (plurality opinion), and includes the right to autonomous choice for certain kinds of important decisions, see Whalen $r$. Roc, 409 U.S. 589, 599-600 (1977). Some cases suggest that the child's constitutionally protected liberty is less extensive than that of an adult, e.g., Tinker v. Des Moines School Dist., 393 L'.S. 503, 515 (1969) (Stewart, J., concurring); Prince v. Massachusetts, 321 U.S. 158, 167-69 (1!44), but the matter sccms unresolved, see Bykofsky v. Borough of Middletown, 429 U.S. 961 , 965 (1977) (Marshall, J., dissenting from denial of certiorari).

117. See p. 206 supra. 
to formulate his own life-plans or personal values, parents are, in general, entitled to choose for him "in accord with their own individual beliefs, preferences, and lifestyles"11s and in light of their own conception of the needs of the family as a whole. ${ }^{119}$ They may, in some cases, be constitutionally protected from compulsion to conform their judgment to the state's standard of what an ideal parent would do.120 In matters that drastically curtail the child's constitutionally protected liberty, however, the scope of parental discretion is not broad enough to include choices on the child's behalf that are only incidentally related to his welfare, or unduly subordinate his interests to the interests of other family members. ${ }^{121}$ These general considerations imply that the psychiatric hospitalization of a pre-adolescent is not within the legitimate scope of parental authority if it rould not promote his mental health, or if it would be more harmful than beneficial, or if it would be no more beneficial than alternative treatments that would restrict his freedom less without significantly increasing the burdens on his family. The state may not sanction the authority of those parents who would " 'farm' out"122 their children to mental hospitals.

Every child has a constitutional right to "rudimentary precautions" against such abuse of state sanctioned power. ${ }^{1233}$ Experience has shown that the child is not adequately protected by a process in which parental discretion is checked only by the need for concurrence of hospital officials. ${ }^{12 \pm}$ On the other hand, procedures that merely transfer primary authority over the psychiatric hospitalization of pre-adolescents from the parents to some agent of the state are not required by the preceding analysis and may intrude too far into the "private realm of family life which the state cannot enter." ${ }^{125}$ Appropriate procedures

118. J. Goldstein, supra note 57, at 648-49.

119. See id, at $655-56$.

120. See, e.g., Carey v. Population Scrvs. Int'l, 431 U.S. 678, 708 (1977) (Powell, J., concurring in the judgment); Wisconsin v. Yoder, 406 U.S. 205 passim (1972).

121. See pp. 198, 204-06 supra.

122. Kent v: United States, 401 F.2d 408, 416 n.4 (D.C. Cir. 1968) (Burger, J., dissenting).

123. See Goss ₹. Lopez, 419 U.S. $565,581-82$ (1975) (for student facing temporary suspension from school, due process clause requires "rudimentary precautions" against unfair, mistaken, or aubitrary official actions).

124. See J.L. v. Parham, 412 Supp. 112, 138 (M.D. Ga. 1976), prob. juris. noted, 431 L.S. 936 (1977), set for reargument, 98 S. Ct. 761 (1978) (No. 75-1690); In re Roger S., 19 Cal. 3d 921, 936, 586 P.2d 1286, 1295, 141 Cal. Rptr. 298, 307 (1977); Ellis, supra note 27, at 864-70 (tendency of hospital staff to overinstitutionalize); Washburn, Vannicelli, Longabaugh \& Scheff, A Controlled Comparison of Psychiatric Day Trealment and Inpatient Hospitalization, 44 J. Consulting \& Clisical Psych. 665, 675 (1976) (bias of psychotherapist toward hospitalization). But see Bartlcy v. Kremens, 402 F. Supp. 1039, 1057 (E.D. Pa. 1975), vacated and remanded as moot, 431 U.S. 119 (1977) (Broderick, J. dissenting).

125. Prince v. Massachusetts, 321 U.S. 158, 166 (1944); see In re B, 497 S.W.Id 831, 837 (Mo. Ct. App. 1973). But cf. Bjerke v. D.T., 248 N.W.2d 808, 814 (N.D. 1976) 
would protect the child's interests while prejudicing the interests of the child's parents or the state as little as possible. ${ }^{1: 0}$

In this context, three factors are most important: first, the procedures adopted to supervise parental admission of pre-adolescents to mental hospitals must be sufficiently inquisitorial to uncover instances of abuse of parental discretion; second, these procedures must not unduly intrude on the privacy and autonomy of the family; ${ }^{127}$ and third, these procedures should not be so formal that they deter parents of children who truly need to be hospitalized from seeking assistance. ${ }^{128}$ In brief, parental admission of pre-adolescents should be quick and easy when the child's need for hospitalization is clear, and progressively more difficult as the propriety of hospitalization becomes more doubtful. ${ }^{129}$

These requirements could be satisfied by an informal conference between the parents and an impartial admissions officer who was independent of hospital authority. His task would be to determine whether the parents had a legally sufficient ground for authorizing the

(state supervention justified where parents refuse to provide needed psychiatric treatment). There is some evidence suggesting that parents of emotionally disturbed children are not the best judges of their children's need for psychiatric hospitalization. See J. Masterson, The Psychiatric Dilemma of Avolescence 43 (1967) (as compared with control group, parents of disturbed adolescents are umable to cope with their own lives effectively). Nevertheless, subjecting the childrearing decisions of parents to direct state supervision runs the risk of infringing upon countervailing constitutional values without appreciably advancing the state's legitimate interest in the welfare of children. See, e.g., Comment, 81 Dick. L. REV. 733, 737-48 (1977).

126. See Mathews v: Eldridge, 424 U.S. 319,335 (1976):

[D]ue process generally requires consideration of three distinct factors: First, the private interest that will be affected by the official action; second, the risk of an erroneous deprivation of such interest through the procedures used, and the probable value, if any, of additional or substitute procedural safeguards; and finally, the Government's interest, including the function involved and the fiscal and administrative burclens that the additional or substitute procedural requirement would entail.

127. A tendency toward excessive intrusions on family life may be a significant characteristic of state practices intended to protect the welfare of children. See, e.g., J. Coldstein, supra note 57, at 651; Levine, supra note 57, at 9-13, 16-18; Comment, supra note 125 , at $749-50$.

128. See Bartley" v. Kremens, 402 F. Supp. 1039, 1058 (E.D. Pa. 1975), vacated and remanded as moot, 431 L.S. 119 (1977) (Broderick, J., dissenting).

129. Because long-term psichiatric hospitalization of children poses such a risk to their future welfare, there may be a good reason to limit parental power even further by requiring, for example. periodic review of psychiatric hospitalizations, cf. Fasulo $v$. Arafeh, 173 Comm. 473, 483, 378 A.2d 553,558 (1977) (due process requires periodic judicial review of civil commitments to mental hospital), or by imposing strict time limits on the duration of such hospitalisations, of. Burt. The Therapeutic L'se and Abuse of State Power

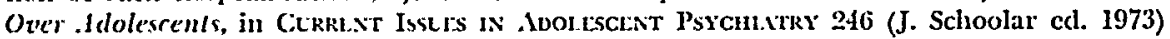
(no adoleseent should be committed to resiclential treatment institution for morc than two montlss). Since these proposals focus on ultimate clisposition rather than on allocation of decisionmaking power among participants, a discussion of them is beyond the scope of this Note. 
hospitalization. ${ }^{130}$ Indicia of a legally sufficient reason would include: whether the hospitalization was significantly related to the child's own mental health and did not serve solely the interests of other family members; whether alternative, less restrictive forms of treatment had been considered or attempted; ${ }^{131}$ whether parents had considered the deleterious side-effects of hospitalization; ${ }^{132}$ and whether the parents were willing to participate in family therapy, if appropriate. ${ }^{133}$ If, after the conference, the admissions officer found that the parents had a legally sufficient reason, the parents would be permitted to admit their child to a mental hospital. ${ }^{134}$ If the admissions officer found, however, that a sufficient reason was lacking, psychiatric hospitalization would not be allowed except by order of a court. ${ }^{135}$ An adverse finding by the admissions officer would, in that way, shift ultimate decisionmaking authority from the parents to the state. Since the purpose of the preadmission conference is not to displace parental authority but only to protect against unwarranted hospitalizations, the pre-adolescent would not have a right to be present or to be represented by counsel. ${ }^{136} \mathrm{But}$

130. To reduce the potential danger to family privacy and autonomy, the admissions officer's power over the parents should be limited to approving or disapproving their application for admission. In particular, he should be barred from initiating or presenting evidence at any proceeding at which the parents' right of custody would be in jeopardy.

131. Children should be placed in mental hospitals only as a last resort, see JoINT Commission on Mental Health of Children, The Mentil Heilth of Childrev: SerVICES, RESEARCH, AND MANPOwer 31 (1973), even though in practice parents often hospitalize children without adequate consideration of the alternatives. sce NIMH, supra note 3, at 21 (Table $\mathbf{N}$ ) (one-fourth of all children and youths admitted to mental hospitals have had no previous psychiatric treatment); Ellis, supra note 27, at 8.51.

132. See p. 204 supra (isolation from family); p. 189 supra (social stigma); $f$. Jorst Commission on Mrntal Health of Children, Coisis in Child Mentit. Hr.ilth: Chal.iengr. FOR THE 1970's 321 (1969) (child necds contact with community for normal development).

133. See, e.g., id. at 90 (successful treatment icquires continuous and close contact betwcen professional staff and family).

134. To encourage a sense of fiduciary responsibility to the child on the part of the admissions officer, he might be required to certify his conclusions to a court whenever he finds that the parents do have a legally sufficient reason for hospitalizing the child. Although this would not limit the officer's discretion or make his finding revicwable by the court, it might serve to deter a perfunctory acquiescence to the wishes of the child's parents.

135. Near-adolescents, those children between the ages of 10 and 14, may have begun the transition from childhood to adolescent thinking. See, e.g., D. ElKIND, supra note 102, at 90; Kohlberg \& Gilligan, supra note 102, at 1062. The procedures governing their psychiatric hospitalization should take this into account. It might be cstablished, for example, that if a near-adolescent still objects to his hospitalization at some specified time after his initial admission (two months seems appropriate), his objection would bo treated as if the admissions officer had found that his parents lacked a legally sufficient reason for authorizing his hospitalization, which could, therefore, continuc only by court order.

136. Cf. Smith v: Organization of Foster Families, 431 U.S. 816, 853-54 (1977) (duc process does not require that child or child's representative be at hearing concerning child's removal from foster family). 
this would change if the admissions officer disapproved the parents' request and they then sought approval of a court. In such circumstances, a full evidentiary hearing at which the child is represented by counsel ${ }^{137}$ should be required.

\section{B. Adolescents}

Because the adolescent is capable of autonomous choice and of formulating his own personal and social values, parental authority to place him in a mental hospital is not justified on either the social control, parental privilege, or family autonomy rationales. ${ }^{138}$ The child's welfare rationale would, in general, justify parental authority over adolescents but only insofar as it is necessary to protect them from their own immaturity. ${ }^{139}$ With respect to psychiatric hospitalization, however, even this rationale is an insufficient support for state sanction of parental authority.

In conflicts between parents and the state, there is good reason to maintain the presumption that parents know best what is in their child's best interests. ${ }^{140}$ But the situation is different in conflicts between parents and their adolescent children. What evidence there is about the interpersonal dynamics of psychiatric hospitalization ${ }^{141}$ and about parental attitudes toward adolescents ${ }^{142}$ indicates that parents

137. Cf. J. Goldstcin, Psychoanalysis and a Jurisprudence of Child Placement-With Special Emphasis on the Role of Legal Counsel for Children (Tent. Draft No. 3A, February 1978) at 13, 17, forthcoming in 1 INT'L J.L. \& Psyck. (1978) (child entitled to counsel once ground has been established that would justify modification or termination of parental custody).

138. See pp. 198, 205, 208 supra.

139. See p. 208 supra. Because the 16-year-old typically has attained his highest level of basic cognitive functioning, see note 109 supra, it might be argued that parental authority over his psychiatric hospitalization should cease altogether. This is currently the law in some states. See note 1 supra (citing statutes); Melville v. Sabbatino, 30 Conn. Supp. 320, 313 A.2d 886 (Super. Ct. 1973).

140. Sec, e.g., J. Goldstein, supra note 57, at 648-51, 654-58.

141. Psychiatric hospitalization often reflects a conflict of interests between parent and child. Parents may hospitalize their child to benefit the family as a whole, see p. 203 \& note 83 supra, or as a means of reasserting their control over the child, see p. 197 \& note 49 sutra. Also, psychiatric hospitalization of children by parents may mask underlying differences in social valucs, see p. 195 \& note 40 supra, or subliminal psychodynamic conflicts within the family, see p. 204 supra. Finally, parents of emotionally disturbed children may have psychological difficulties of their own that undermine their capacity to act as decisionmaker for the child. See J. Masterson, supra note 125, at 43, 152.

142. Adults may misunderstand the adolescent because their perceptions of and attitudes toward him are affected by their own psychological needs. See, e.g., Byng-Hall \& Miller, Adolescence and the Family, in Adolescencr: 'The Crises of Adjustaent 59.62, 64-65 (S. Areycrson ed. 1975); Cohen \& Balikov, On the Impact of Adolescence $C_{p o n}$ Parenis, in 3 ADolescent Psychittky 217 (S. Feinstein \& P. Giovacchini eds. 1974) (adolescence itself is noxious to parents, who feel need to rid themselves of it). 
should not be presumed to know best whether psychiatric hospitalization will serve the best interests of their child when the adolescent himself objects. Moreover, unless it is assumed that this is a matter about which parents will never err, there is not a fair and substantial relationship between the state's objective of protecting adolescents from their own immaturity and a statute that prevents the adolescent from ever having the opportunity to contest his hospitalization before a neutral adjudicator. Because the adolescent's interest in not being involuntarily confined in a mental hospital is constitutionally protected, ${ }^{143}$ legislation cannot intrude upon it any more than is necessary to achieve a legitimate state objective. ${ }^{14 *}$ Therefore, even though the state may seek to protect adolescents from their own immaturity, unreviewable parental authority over the psychiatric hospitalization of adolescents-like an absolute parental veto over an abortion ${ }^{14 \bar{j}}-$ is constitutionally proscribed. Parents of an adolescent may be entitled to counsel and persuade, but they are not entitled to consent on his behalf.

It does not automatically follow that the state is required to give the adolescent's choice for himself the same legal effect as that of an adult, but the state must recognize that the adolescent is capable of formulating his own conception of what would promote his own best interests. An adolescent no longer speaks only through his parents; to some extent he speaks for himself. In recognition of this, he must be permitted to influence directly decisions that encroach upon his fundamental rights. ${ }^{1+6}$ Specifically, when the parents of an adolescent seek to place him in a mental hospital and he objects, it is not enough that there be some mechanism that would protect the adolescent from his parents' mistakes. The adolescent must also be afforded a forum in which that dispute may be resolved and a meaningful opportunity to make his case. He has, in short, a right to be heard. ${ }^{147}$

143. See pp. $188-89$ supra.

144. See Roe v. Wade, 410 U.S. 113, 155 (1973); Developments, supra note 9, at 1210 , 1222-23.

145. See Planned Parenthood v. Danforth, 428 U.S. 52, 74 (1976); id. at 90.91 (Stewart, J., concurring).

146. Sce notes 66 \& 95 supra (citing cases); cf. Goss v. Lopez, 419 U.S. 565, 583.84 (1975) (due process requires informal give-and-take between student and school disciplinarian when student subject to suspension).

147. The Supreme Court has recently held that there are some cases in which a person deprived of a constitutionally protected liberty interest is not entitled to a hearing of any sort. Ingraham v: Mright, 430 U.S. 651, 682 (1977) (corporal punishment of schoolchild). The basis of the Court's holding, howerer, was that there was only a minimal risk that without a hearing the child's substantive rights would be violated and that the marginal 


\section{Mental Hospitalization of Children}

Precisely what form that hearing must take will depend on weighing the various interests at stake against the social costs and benefits of alternative procedural arrangements. ${ }^{148}$ Fairly formal evidentiary hearings have been required where the consequence of an adverse determination was a substantial loss of liberty ${ }^{140}$ or where the risk of error was high. ${ }^{150}$ The decision whether to commit an adolescent to a mental hospital has both these characteristics. ${ }^{151}$ Moreover, the two courts that have specifically addressed this issue concluded that due process would be satisfied only by a hearing at which the child could present evidence in his own behalf, confront and cross-examine adverse witnesses, and be represented by counsel. ${ }^{152}$ It would seem, therefore, that only by being afforded such an evidentiary hearing could "the appropriate due process balance" 153 be struck.

\section{Conclusion}

The conclusions reached here follow from an analysis of the scope of parental authority as it has been defined by the legal tradition and

benefits of additional safeguards would be outweighed by their adverse effects on the school environment. Id. at 681-82. Those considerations do not apply here. See note 151 infra (high risk of error).

The adolescent's right to a hearing derives from the presumption that he is minimally competent to choose for himself. The presumption is not irrebuttable. Should it be conclusisely determined at or before the hearing that the adolescent suffers from a mental defect so severe that the normal presumption is in his case false-if, for example, he is severely mentally retarded-then the standards and, where appropriate, the procedures for the pre-adolescent would apply. A finding that the child is mentally ill, however, is not by itself sufficient to reverse the presumption of competence, see note 112 supra, and, hence, abrogate his right to be heard.

148. See Mathews v. Eldridge, 424 U.S. 319,335 (1976).

149. See Morrissey v. Brewer, 408 U.S. 471, 483-84 (1972) (suspension of parole); In re Gault, 387 U.S. 1, 28.30 (1967) (adjudication of delinquency).

150. Compare Goldberg v: Kelly, 397 U.S. 254, 267-69 (1970) (requiring hearing because disposition turned on questions of credibility) with Mathews v. Eldridge, 424 U.S. 319 , 343.47 (1976) (no hearing required because disposition turned on objectively determinable medical fact).

151. The risk of error is high because questions of psychiatric hospitalization may be infused with matters not dircety related to the child's mental health, see pp. 195-97, 203-04 supra, and because there is a significant potential for adults to misinterpret an adolescent's conduct, see note $\mathbf{1 4 2}$ supra. Moreover, psychiatric evaluation, which is fraught with uncertaintics, see, e.g., Ennis \& Litwack, Psychiatry and the Presumption of Expertise: Flipping the Coins in the Courtroom, 62 Calıf. L. Rev. 693, 719 (1974) may be particularly difficult for adolescents, see R. Hudgens, Psychiatric Disorders in AdolesCENTs 7 (1974); Mceks, Nosology in Adolescent Psychiatry: An Enigma Wrapped in a Whirlwind, in Current Issues in Adozrscent Psychiatry 93-96 (J. Schoolar ed. 1973).

152. Bartley v. Kremens, 402 F. Supp. 1039, 1053 (E.D. Pa. 1975), vacated and re. manded as moot, 431 U.S. 119 (1977); In re Roger S., 19 Cal. 3d 921, 937-38, 569 P.2d 1286, 1296, 141 Cal. Rptr. 298, 308 (1977).

153. Mathews v. Eldridge, 424 U.S. 319, 347 (1976). 
moral values of this nation. Whether a parent may constitutionally choose to admit his child to a mental hospital should depend on three factors: first, the extent to which the decision intrudes on the child's constitutionally protected interests; second, the extent to which the underlying purposes of parental authority are valid and are furthered by its exercise in this context; and third, the extent to which the child is capable of making the choice for himself. This analysis has broader implications: in any context in which the interests of parents and children conflict, it offers a general method for defining where parental authority ends and children's constitutional rights begin. 